\title{
A NÉPESSÉGTUDOMÁNYI KUTATÓINTÉZET TÖRTÉNETE ÉS A NÉPESEDÉSPOLITIKA A KÁDÁR-RENDSZERBEN
}

\section{Bódy Zsombor}

\section{ÖSSZEFOGLALÓ}

A cikk a magyar demográfia történetét vizsgálja a Kádár-korszakban elsősorban a politikai hatalom és a szakma kölcsönös kapcsolatai, illetve a korszak népesedéspolitikai intézkedései szempontjából. Bár a demográfia az 1950-es évek végén, a '60-as évek elején intézményesült tudományként, valójában az államszocializmust megelőző időszak tudományos hagyományaira épített. Az NKI alapítása és rendszerváltásig tartó müködésének története azt mutatja, hogy a demográfia rendelkezett korlátozott szakmai autonómiával - és kitűnő nemzetközi beágyazottsággal - az 1960-as, '70-es és '80-as években. A demográfia legfontosabb hazai tudományos mühelyei nem láttak el előkészítő feladatokat a pártállami család- és népesedéspolitikai döntésekkel kapcsolatban, s többnyire nem is tudták befolyásolni a döntéshozókat, bár egyes demográfusokban meg lett volna erre az igény. A tanulmány bemutatja, hogy a legfelső szintü döntéshozókat milyen szempontok vezették a népesedéspolitikai döntések meghozatalánál.

Tárgyszavak: Kádár-kor, népesedéspolitika, demográfia-történet, Népességtudományi Kutatóintézet

Bódy Zsombor

Pázmány Péter Katolikus Egyetem BTK Szociológiai Intézet

E-mail: body.zsombor@btk.ppke.hu 


\section{BEVEZETÉS}

A demográfia tudománya, illetve a népesedési kérdésekre vonatkozó tudás - talán más társadalomtudományoknál is közvetlenebbül - függ össze értékválasztásokkal, illetve politikai víziókkal. A népesedéspolitikai gyakorlatok éppen ezért mindig olyan konstrukciókra épülnek - éppen úgy, mint bírálataik -, amelyek még felületesen nézve sem értéksemlegesek (Greenhalgh 1996, Melegh 2000). A demográfia politikai értékvonatkozásaiból következik, hogy a népesedéspolitikai témákra vonatkozó tudás felépítése nem csak belülről bír - diszkurzív - politikai tétekkel, de soha nem semleges kérdés a politikai hatalom számára sem. A demográfia területén tevékenykedők mindig is számíthatnak az intézményes, a demográfiához képest külső politikai hatalom vagy annak egyes ágensei érdeklődésére is. A népesedési kérdések a 20. századi Magyarországon is azon témák közé tartoztak, amelyek a mindenkori hatalom érdeklődése/ellenőrzése alatt álltak, miközben a róluk folytatott diskurzusok eleve belülről is átpolitizáltak voltak. Nem volt ez másként a Kádár-korszakban sem, amikor éppen ezek a kérdések váltak alkalmassá arra, hogy vitatásukon keresztül az ellenőrzött nyilvánosság viszonyai közepette is bírálni lehessen a „rendszert”. A népesedési kérdések - amelyeket elsősorban a termékenység kérdésére redukáltak -, nemcsak rendszerkritikus vélemények anyagául szolgáltak a kádárizmus évtizedeiben, hanem a modernitáshoz, a hagyományosnak vélt paraszti társadalom felbomlásához, a (szocialista) fogyasztói társadalom értékeihez való különféle viszonyulások, sőt különféle nemzetfelfogások ütközésének terepéül is szolgáltak. A népesedési diskurzusok ilyen összetett szerepének felismerése késztetett szociológusokat arra, hogy már a korszak végén elemzésnek vessék alá az 1960as és az 1970-es évek népesedésről szóló vitáit (Heller - Némedi - Rényi 1990). Az elkészült tanulmány több korlátba ütközött. Nem tudott választ adni arra a kérdésre, hogy az elemzett nyilvános megszólalások pontosan milyen befolyással bírtak a népesedéspolitikai döntéshozatalra, mert források hiányában nem lehetett akkor képet alkotni arról, hogy a hatalmat milyen szempontok vezették ezen intézkedések kapcsán. Nem volt világos az sem, hogy pontosan milyen hatások érvényesültek a tudós demográfus szakma és a hatalom között. Mennyiben határozta meg a politikai hatalom a demográfiának mint tudománynak a működését, mennyiben támaszkodott népesedéspolitikai döntéseknél a tudomány eredményeire, vagy más szempontból nézve a kérdést, befolyásolta-e a demográfus szakma - szakértői szerepben lévő művelőin keresztül - a politikai 
döntéshozatalt. A nyilvános diskurzus, a tudományos demográfia, valamint a politikai hatalom viszonyrendszere tehát jelentős részben homályban maradt.

A nyilvános diskurzusok elemzése mindenesetre éles bírálatokat váltott ki a demográfia tudományos művelői közül. A Heller Mária, Némedi Dénes és Rényi Ágnes által készített tanulmány azon állitása, miszerint a népesedési folyamatok bármilyen alakulása mellett is, nem szólnak logikailag kényszerítő érvek egy pronatalista népesedéspolitika mellett - „Miért kell értékesebbnek tartanunk azt az állapotot, amikor több gyerek születik?” (Heller et al. 1990: 86) -, a vitában felszólaló demográfusok számára nem volt elfogadható. Többek között Andorka Rudolf és Dányi Dezső is elutasitották ezt az alapállást, sőt azon véleményüknek adtak hangot, hogy egyes írói csoportok nyilvános fellépése hasznos volt, amennyiben felhívta a figyelmet a problémára, és arra kényszerítette a politikai vezetést, hogy lépéseket tegyen a népesedéspolitika terén. Így tulajdonképpen egyetértettek a szociológus elemzők azon meglátásával, hogy az íróknak tágabb lehetőségei voltak a megszólalásra, mint a tudományos intézményrendszerhez, vagy éppen a KSH-hoz mint kormányzati szervhez kötött demográfusoknak (Cseh-Szombathy László, Andorka Rudolf hozzászólása [Monigl 1990: 127-179.]). A népesedési tényektöl függetlenített diskurzuselemzés azonban lényegében emészthetetlennek bizonyult valamennyi demográfus, statisztikus hozzászóló számára (Miltényi Károly, Hoóz István stb.), akiknek magától értetődő volt, hogy a korösszetétel tényleges alakulása a munkaerő-kínálat problémái és a szociális ellátórendszer túlterhelése révén „kedvezőtlen”, fejlődést korlátozó, illetve össztársadalmi szinten költséges. ${ }^{2}$

Jelen kutatást azzal a kérdésfeltevéssel kezdtük el, hogy miként működött, mekkora autonómiát élvezett a demográfia mint tudomány, amely elsősorban a KSH Népességtudományi Kutatóintézetben összpontosult a Kádár-rendszerben. Mennyiben határozta meg a politika a tudomány működését, befolyásolta a kutatási témákat akár pozitív értelemben, ha megrendelt vizsgálatokat, akár

\footnotetext{
${ }^{1}$ A Heller - Némedi - Rényi tanulmány célkitüzése más szempontból eleve korlátozott volt. Nem a demográfiai tudás felépitésének mikéntje és politikai tétjei érdekelték, s nem is nemzetközi léptékben vizsgálódott. Az elemzés kifejezetten a magyar népesedési diskurzusok szerkezetének feltárására vonatkozott.

${ }^{2}$ A tanulmányt persze nem csak a hivatásos demográfusok bírálták. Teljes elutasitásra talált Fekete Gyulánál is, akinek szövegei többek között a diskurzuselemzés tárgyául szolgáltak. „Tisztelt Monigl István! Olvastam - eljuttatták hozzám barátilag - dolgozatukat a demográfiai vitákról. A szerzők természetesen nem adhatnak mást, csak mi lényegük - no de ezért bizzták meg éppen öket a téma kidolgozásával. Ön ezt a szánalmasan elfogult, prekoncepciós, a tényeket lépten-nyomon meghamisító, ártó indulatokkal telített dolgozatot tudományosnak minősitette azáltal, hogy zártkörủ szakmai vitára bocsátja, s ezzel - túl az inspiráción - mintegy a felelősséget is vállalja érte. Személy szerint Önnek fogom megválaszolni a nyilvánosság elött kellỏ időben, kellő alkalommal. A felelősség demográfiai tragédiánkért történelmi súlyú, már sohasem avul el. Rajta leszek, hogy ne kapjanak felmentést, akik a tragédia elöidézésében s mai elmélyitésében bünösök. Fekete Gyula" 1988. V. 27. dátumú levél, KSH Irattár B - 1.1. 63. doboz.
} 
negatív értelemben, ha letiltott kutatási témákat. A másik oldalról pedig menynyiben játszott szerepet a tudomány - akár információk szállítójaként, akár aktív befolyásoló, sugalmazó félként - a népesedéspolitikai döntésekben? A kutatás tehát egy sajátos társadalomtudomány Kádár-kori történetét célozta feltárni. A munka során jórészt lehetővé vált, hogy az 1980-as évek végén keletkezett szociológusi elemzés által nyitva hagyott kérdésekre is megpróbáljunk felelni. Vagyis az immár hozzáférhető források tükrében felvázoljuk egyrészt azt, hogy miIyen szempontok mozgatták a politikai döntéshozókat - gyakorlatilag az MSZMP vezetőit - a népesedéspolitikai döntéseknél, másrészről pedig azt, hogy milyen szerepet játszott ebben a demográfia mint tudomány. A tanulmány célja tehát igen csak korlátozott. Nem célunk a demográfiai módszerek és kutatások történetének áttekintése, még kevésbé a demográfiai tudás nemzetközi felépülésének és szerkezetének vizsgálata. A magyar demográfia intézményesülésének történetéhez szeretnénk adalékokkal hozzájárulni, a demográfia és a politikai hatalom kapcsolódásait amennyire lehet megvilágítani, s egyúttal a kádári hatalom népesedési kérdésekhez való viszonyát bemutatni.

A kutatás során világossá vált, hogy két szempontból is helytelen, ha a vizsgálódás során nem tekintünk túl az 1950-es, 1960-as évek fordulóján, s csak a már konszolidált Kádár-rendszer időszakában vesszük szemügyre a népesedési kérdések, illetve a demográfia helyzetét. Bár igaz, hogy több más társadalomtudományhoz hasonlóan az 1960-as évek elején a hazai demográfia újjászületést élt meg, ám ez nem jelentette azt, hogy ne lettek volna erős szálai a kontinuitásnak a korábbi korszakokkal. Ugyanakkor a politikai rendszer sem az 1960-as évek elején kezdett el foglalkozni népesedési kérdésekkel.

\section{A DEMOGRÁFIAI KUTATÁSOK ÚJRAINDULÁSA ÉS INTÉZMÉNYESÜLÉSE}

Az ún. Ratkó-korszak - valójában mindössze két év - intézkedései a pártvezetés részéről az 1950-es évek elején mutatkozó születésszám visszaesésére adott válaszok voltak (Tárkányi 1998). ${ }^{3}$ Az abortusz erőteljes adminisztratív üldözése, a gyermektelenségi adó, a szülés propagálása a születésszám jelentős átmeneti emelkedéséhez vezetett, ugyanakkor feszültségeket eredményezett a gyermekeket befogadó intézményhálózat szűk keretei miatt, nem utolsósorban pedig ne-

\footnotetext{
${ }^{3}$ Az 1952-53-as intézkedésekről különösen: 245-246. 0. A politika a születésszám visszaesését egészségügyi és - nem annyira magán, mint inkább politikai - erkölcsi kérdésként kezelte.
} 
gatív politikai visszahatása lett, mert a társadalom széles rétegei a magánéletbe, a személyes döntésekbe való durva beavatkozásként értékelték az intézkedéseket. 1956-ra a hatalom visszakozott, és a korábbi teljes tiltást egy nagyon is liberális abortuszszabályozással váltotta föl (a gyermektelenségi adó már korábban megszűnt). Későbbi elemzés szerint a születésszám emelésére tett emez első szocialista kori intézkedések kudarca a Kádár-korszakra nézve is meghatározó tapasztalatot jelentett a hatalom számára. Innen eredeztették, hogy a rendszer mindig óvatosan nyúlt a népesedési kérdésekhez, inkább reagált a folyamatokra, semmint tervezni, vagy irányítani próbálta volna azokat (Monigl - Dányi 1987).

A Rákosi-korszak kudarcos népesedéspolitikai kísérlete következményeiben hozzájárult a demográfia tudományának magyarországi új kibontakozásához is. A magas, forszírozott születésszámot ugyanis a termékenység drasztikus visszaesése követte, különösen 1956 után. ${ }^{4}$ Az első népesedéspolitikai kísérlet kudarca és a születésszám zuhanása megérlelte a fogadókészséget a hatalom részéről is a népesedési kérdések szakszerübb megközelítése iránt. A másik oldalról a demográfiai kutatások újraindításához adott volt egy szűk, de képzett szakemberállomány, amelyben meg is volt a készség a demográfia tudományos keretek között való müvelésére.

A Demográfia folyóirat 1958-ban indult, ám csak az 1959. évi első számában találhatunk egy olyan szöveget, amely az induló folyóirat beköszöntőjének tekinthető. Ez a szerző nélküli, mintegy szerkesztőségi nyilatkozatként megjelenő szöveg ugyan röviden leszögezi, hogy az elmúlt tíz évben a hazai statisztika és demográfia hatalmas fejlődésen ment át, ám explicit megállapítja azt is, hogy a hazai statisztikában és demográfiában a tudományos szempontok 1948 után háttérbe szorultak. Miközben a statisztika a népgazdasági tervezés gyakorlati céljait szolgálta - azt sem mindig hatékonyan -, elmaradt a megfigyelt folyamatok mélyebb, tudományos elemzése. Ezzel a megállapítással az áttekintés a Demográfia megindulását a tudományos munkához való visszatérésként értékeli. Az írás szerint gyors gazdasági változások és a társadalmi átrétegződés, illetve a nagy léptékű vándormozgalmak közepette, valójában a tervezés hosszabb távú érdekeit is - túlmenve az egyszerű tájékoztatáson - csak tudományos igénnyel lehet szolgálni (KSH NKI 1959).

A kapcsolódást a pártállami átalakulás előtti idők előzményeihez nyíltan is vállalták. 1936-tól létezett a Nemzetközi Népességtudományi Uniónak egy magyar csoportja - magyar tagjai korábban is voltak a szervezetnek -, amely több, mint tíz éven át rendszeres munkát fejtett ki. Ennek tevékenységét a Demográ-

${ }^{4}$ Az 1950-es évekbeli 200 ezres csúcsról 1962-re 130 ezerre csökkent az élveszületések száma. 
fiában pozitívan értékelték, s a demográfiai kutatások és publikációk ismételt megjelenését az egy évtizeddel korábban megszakadt munka újrafelvételének tartották (Thirring 1959: 411). A folyóiratban szerepeltek olyan idősebb szerzők is, mint a két világháború közötti közgazdaságtudomány reprezentánsának számító Varga István ${ }^{5}$, vagy, mint a komoly nemzetközi tudományos elismertséggel rendelkező idős matematikus, Jordán Károly. Elmondható az is a Demográfia első évfolyamai alapján, hogy a magyar demográfus szakma - nyilvánvalóan a korábbi korszakok örökségeként - széles nemzetközi rálátással rendelkezett. A folyóirat tudósított a népességtudomány eredményeiről, beszámolt külföldi kutatásokról, publikációkról és konferenciákról, sőt külföldi, nyugati szerzők is aránylag gyakran felbukkantak a Demográfia első tíz évfolyamában. ${ }^{6}$ Nemzetközi konferenciákon magyar kutatók is rendszeresen részt vettek a Demográfia Figyelő rovatának tanúsága szerint. Leggyakrabban Péter György, a KSH elnöke, Szabady Egon, a KSH egyik elnökhelyettese, akik pozíciójuknál fogva hivatalos meghívottak voltak, ám rajtuk kívül fiatalabb, akkor többnyire harminc körül járó demográfusok is, mint Klinger András, Miltényi Károly, Vukovich György, Valkovics Emil, Tamásy József is rendszeres részt vevői voltak nemzetközi szakmai rendezvényeknek. Megjegyzendő, hogy közülük a fiatalabbak, akik pályájukat 1948 után kezdték, szintén kapcsolódtak a korábbi korszak statisztikájához annak révén, hogy Varga István tanítványai voltak az egyetemen még az 1940-es évek második felében (Hoóz 2016: 126-127.).

A Demográfia folyóirat elindulása nem az egyetlen eseménye volt a hazai népességtudomány kibontakozásának. Kicsivel megelőzte a történeti demográfia intézményesülése a KSH könyvtárához kapcsolódva (Faragó 2015: 17-19.). A Demográfia elindulása után nem sokkal pedig akadémiai keretek között is intézményesült a demográfia tudománya. 1960-ban alakult meg az MTA Demográfiai Elnökségi Bizottsága.? Ez a testület eleinte nem tartozott valamely akadémiai osztályhoz, hanem közvetlenül az elnökség alá tartozott. Az MTA Demográfiai Elnökségi Bizottsága élén Péter György állt, titkára Szabady Egon volt, aki a bizottsági ülések jegyzőkönyvei szerint a legaktívabb, meghatározó személyisége volt e testületnek (később Szabady a bizottság alelnöke lett, majd Péter halála után az elnöke). A bizottság - amely a KSH munkatársai közül már alapításakor

\footnotetext{
5 1897-1962, a Magyar Gazdaságkutató Intézet vezetője 1927-től.

${ }^{6}$ Ezek a tanulmányok rendszerint megjelentek már korábban más nyelveken, a magyar demográfusok pedig ezeket az eredeti nyelveken is el tudták olvasni. Így lehetséges, hogy lefordíttatásuk és publikálásuk elsősorban a tudatos nemzetközi kapcsolatépitést szolgálta.

${ }^{7}$ Az MTA elnöksége - Rusznyák István elnök, az alelnökök és Erdei Ferenc főtitkár - 1960. május 13-án döntött a testület felállításáról.
} 
soraiban tudhatta Klinger Andrást, Vukovich Györgyöt és Miltényi Károlyt - első három rendezvényén a népesedési helyzetről, a születésszám alakulásáról, valamint a születésszám befolyásolásának lehetőségeiről folytatott vitát (KSH NKI 1961). Ezek a témák az 1956 után évről évre jelentősen csökkenő születésszám miatt akkor nyilvánvalóan érdeklődésre tarthattak számot, s az állami apparátusokat, illetve a politikai hatalmat is foglalkoztatták. E rendezvénysorozat mellett az MTA Demográfiai Elnökségi Bizottsága igyekezett előmozdítani a demográfia tudományának intézményesítését is. Ennek részeként létrehozták a Demográfiai Tudományos Minősítő Bizottságot - tagjai: Péter György, a KSH elnöke, Erdei Ferenc és Ember Győző történész, az Országos Levéltár igazgatója8 -, amely közreműködött a Népességtudományi Kutató Csoport megalapításában is.

\section{POLITIKAI ÉRDEKLÖDÉS A NÉPESEDÉSI FOLYAMATOK IRÁNT AZ 1950-ES ÉS 1960-AS ÉVEK FORDULÓJÁN}

A demográfia fenti intézményesüléséhez minden bizonnyal a politikai vezetés részéről a népesedési kérdések iránt meglévő érdeklődés is hozzájárult. Péter György KSH elnök 1959 nyarán egy előterjesztésben tájékoztatta a párt- és állami vezetést a születésszám csökkenéséről, amelyben az is szerepelt, hogy a terhességmegszakitás szigorítása nem lehet a kérdés kezelésének módja, mert az az illegális, egészségügyi szempontból veszélyes abortuszok számát növelné (Monigl 1992: 13-21.). Az Egészségügyi Minisztérium a Minisztertanács utasítására 1961 júniusában jelentést készített a születésszám alakulásáról - elsősorban a KSH adatai alapján -, amely a csökkenés okai között már azt is említette, hogy a mezőgazdaság kollektivista átszervezésének hatására a születésszám nagymértékben visszaesett falun (Monigl 1992: 43-52.). Ezt követően, 1962 tavaszán a KSH előterjesztést nyújtott be az MSZMP Központi Bizottságának (KB) a népesedési helyzetről, amelyben számos intézkedést is javasolt. Többek között azt is, hogy a Politikai Bizottság (PB) utasítsa az MTA Demográfiai Elnökségi Bizottságát egy az anyaság megbecsültségét fokozó propaganda koncepciójának a kidolgozására (Monigl 1992: 55-61.). Az előterjesztés elkészülte és javaslatai azt mutatták, hogy a KSH demográfusainak határozott álláspontja volt a népesedési kérdésekről, és igyekeztek is ezt érvényre juttatni a politikai vezetésnél. A párt vezetői azonban - bár aggasztotta őket a születésszám csökkenése - nem bizonyultak olyan könnyen befolyásolhatónak.

\footnotetext{
${ }^{8}$ Az első kutató, aki kandidátusi fokozatot szerzett demográfiából, Hoóz István volt 1966-ban.
} 
Az előterjesztést az MSZMP KB Államgazdasági osztálya néhány csekély változtatás után átadta a Nyers Rezső vezetette MSZMP KB Államgazdasági Bizottságának tárgyalásra, de az ez alkalommal Péter Györggyel is kiegészült bizottság csak átdolgozás után tartotta a PB-nek bemutathatónak. Az előzetes anyagban szerepelt egy javaslat a házasulandóknak nyújtandó családalapítási kölcsönröl, amelyet a gyermekek szülésével is törleszteni lehetne. Az ÁGB ezt nem támogatta, viszont helyette a bölcsődei hálózat kiterjesztésének szükségességéről kért egy betoldást a szövegbe, ami be is került a PB elé kerülő anyagba. ${ }^{9}$

Az átdolgozott előterjesztést 1962. június 12-én tárgyalta meg a Politikai Bizottság. A szöveg elmagyarázta a PB-nek a teljes termékenységi arányszám fogalmát és azt, hogy ez miért alkalmas mutató a hosszabb távú trendek bemutatásához. (Kádár János - aki a jegyzőkönyv szerint a korábban elterjedt szóhasználatot követve „aborduszként” emlegette a terhességmegszakitást - hozzászólásából láthatóan megértette a fogalmat.) A nemzetközi összehasonlításban is bemutatott magyarországi termékenység alacsony szintjének okaként az előterjesztés a népesség foglalkozási átrétegződését, a mezőgazdaság „szocialista átszervezését”, a nők munkába állását, a tanulmányi idő átlagos hosszabbodását és a városiasodást jelölte meg. A termékenység növelését az anyag feltétlenül szükségesnek tartotta, ennek módozataival kapcsolatban viszont óvatosságot ajánlott. Leszögezte, hogy nemzetközi tapasztalatok alapján az abortusz megszigorításával nem lehet tartós eredményt elérni, s ez politikailag is káros intézkedés lenne. Ez utóbbi megállapítással a PB egyhangúlag egyetértett. Az előterjesztés lehetséges intézkedéseként a bölcsődei hálózat fejlesztését (az anyaság és a munka könnyebb összeegyeztethetőségének érdekében), a családi pótlék emelését, valamint az anyák számára „,három éves fizetett szülési szabadságot” vette számba. A PB ekkor nem döntött semmilyen új intézkedésről. Ahogy Gáspár Sándor - KB gazdaságpolitikai titkára, egyben PB tag, később a SZOT elnöke - összegezte a kialakult álláspontot, „[r]iasztó hírek érkeztek, ezért a Politikai Bizottság kérte ezt a jelentést. Ki nem pusztul a nemzet és majd annak idején, amikor az életszínvonal emelésével kapcsolatos konkrét intézkedéseket foganatositjuk, ezen a téren is lehet csinálni valamit."10

\footnotetext{
${ }^{9}$ Az Államgazdasági Bizottság 1962. június 2-ai ülésének jegyzőkönyve MNL 288. f. 15/47. ő. e.

${ }^{10}$ A PB 1962. június 12-ei ülésének jegyzőkönyve MNL OL 288f 5/267, ö.e.
} 


\section{A demográfiai kutatóhely létrejötte és tudományos profilja}

A politikai hatalom - és következésképp a különböző állami apparátusok - népesedési kérdések iránti megnövekedett érdeklődése mellett és a vázolt tudományintézményesülési előzmények után került sor a Népesedéstudományi Kutató Csoport (NKCs) létrehozására. Az MTA Demográfiai Elnökségi Bizottságának a különböző témákban tartott vitaülésein túl legfontosabb tevékenysége a kutatócsoport létrehozásának támogatása volt, majd a NKCs müködésének felügyelete (az NKCs volt az egyetlen kutató intézmény, amelyet felügyelnie kellett).

A KSH szervezetén belül elvileg 1962. január 1-től alakult meg a Népességtudományi Kutató Csoport - eleinte három fővel és Szabady Egon vezetésével - az akkor szintén a Szabady Egon által vezetett „Népesedési és Szociálstatisztikai főosztály" alá rendelve. Ám még ugyanezen év őszén is arról jelent meg tudósitás, hogy a csoport szervezése folyamatban van, bár már kutatások is folynak ott (MTA Demográfiai Elnökségi Bizottság 1963). 1964-re a Népességtudományi Kutató Csoport a főosztályokkal egy sorba emelkedett, és sok más főosztályhoz hasonlóan Szabady alelnök felügyelete alá tartozott.

A csoport létrejöttét a hivatalos indoklás szerint az tette szükségessé, hogy a KSH-ban addig folytatott, egyre növekvő mennyiségű demográfiai kutató munka már nem tudta kielégíteni a különböző minisztériumoknak, főhatóságoknak és tudományos intézeteknek a népességtudománnyal szemben támasztott elvárásait. A fokozódó igények e mellett módszertani téren is éreztették hatásukat, ezért a csoportnak több, sajátos módszertani problémát kell kidolgoznia, eddig nem alkalmazott módszerek felhasználásának lehetőségeit megvizsgálnia. Tevékenységének ezért kétirányúnak kell lennie az indoklás szerint: részben a tervezés, különösen a távlati tervezés szempontjából fontos demográfiai kérdéseket vizsgálja és elemzi, részben pedig a népességtudomány tovább fejlődése érdekében végez kutatómunkát, elsősorban azokban a tárgykörökben, amelyek a demográfia nemzetközi érdeklődésének előterében állnak."

Az 1962. januári hivatalos indulás természetesen azt jelentette, hogy az erre vonatkozó határozatok már 1961-ben megszülettek. A Minisztertanács Gazdasági Bizottságának 4218/1961. sz. döntése hagyta jóvá a NKCs megalapítását. A Tudományos és Felsőoktatási Tanács 209/1962. sz. döntésével azután helybenhagyta az intézmény életre hívását. Erre hivatkozva Péter György KSH elnök 1962 augusztusában javasolta Nyers Rezső pénzügyminiszternek, hogy

"Demográfia, 1962, 5(1), 110. 
a Pénzügyminisztérium (PM) póthitel révén tegye lehetővé 7 fő új felvételét a NKCs-be, amit kiegészítenének még 13 fö áthelyezésével a Népszámlálási osztályról. Erre azonban nem került sor, a KSH elnöke később arról panaszkodott egy - Kolos Richárdnak, a Tudományos és Felsőoktatási Tanács Főtitkárának írt - levelében, hogy az NKCs az eredetileg 1965-re elérni tervezett 25 fős létszám helyett, még 1965 novemberében is 12 fővel müködik, ráadásul a PM még 1966ra sem hajlandó újabb státusokat finanszírozni. ${ }^{12}$ A lassú létszámnövekedés után 1968. január 1-jével minősítette át a KSH elnöke az addigi kutatócsoportot Népességtudományi Kutatóintézetté, amelyen belül ezzel különböző osztályok is létrejöttek. Először a Módszertani és Általános Demográfiai osztály, valamint a Társadalom- és Gazdaságdemográfiai osztály jött létre - az előbbit Tekse Kálmán, az utóbbit Vukovich György vezette -, illetve az Intézet könyvtára is külön szervezeti egységet képezett (ekkoriban mintegy 20 „,tőkés folyóiratot” járattak a demográfia tárgyköréhez kapcsolódóan). Később önálló gazdasági csoport is alakult.

A Népességtudományi Kutató Csoport, majd Intézet létrejöttével a demográfia intézményesülésének újabb fontos lépése történt meg, amikor az MTA-hoz is kapcsolódva létrejött egy olyan kutatóhely, amelynek feladatai között az alapkutatások és módszertani kérdések vizsgálata is szerepelt. Már a kutatócsoport indulásakor kialakult az a rendszerváltásig fennmaradó konstrukció, miszerint a Népességtudományi Kutatóintézet a KSH részeként müködik, ám szakmai, tudományos felügyeletét az MTA illetékesei - konkrétan a Demográfiai Bizottság, amely 1965-től már nem az elnökség, hanem a IX. osztály alá tartozott - látták el, és az itt folyó kutatások finanszírozásában is szerepet vállalt az Akadémia.

A Demográfiai Bizottság évente javaslatot készített az MTA elnökségének a NKCs-ben folyó kutatások akadémiai támogatásáról. Az előterjesztésekből pontosan látszik, hogy az első években kik, milyen kutatásokat folytattak, és azt miből finanszírozták. Hat alkalmazott kutatásnak minősülő program futott, amelyek „felhasználási helyeként” az Országos Tervhivatalt jelölték meg. Ezek: a családok és a háztartások számának, nagyságának és lakásszükségletének előreszámítása; a családok életciklusának vizsgálata; a társadalmi átrétegződés és a demográfiai jelenségek összefüggéseinek vizsgálata; a népesség-előreszámítások; a mezőgazdasági népesség távlati foglalkoztatási problémái; a népesség iskolai végzettsége és szakképzettsége; a népesség lakóhely-változtatásának vizsgálata voltak. A felsorolt témák részben nem tisztán demográfiai - bár demográfiai vetülettel is bíró - kutatások voltak, amelyek eredményeit az akkor

\footnotetext{
12 Péter György levelei: MNL OL XXXII-23-i-6.1. 1. doboz.
} 
állandóan zajló tervezési folyamatokban tartották felhasználhatónak. Ezen kívül tíz másik kutatási projekt is folyt a legkülönfélébb témákban.

A kutatások nagy száma a kutatócsoport csekély létszámához képest úgy volt lehetséges, hogy egyrészt valamennyi munkatárs több programban is részt vett - gyakori volt, hogy valaki az egyikben vezető, a másikban pedig részt vevő, és fordítva -, másrészt a KSH más részlegeiből is közremüködtek akár projektvezetőként is a kutatásokban (például Klinger András, Barta Barnabás), végül pedig nyugdijas statisztikusokat is foglalkoztattak.

Itt ismét az 1945 előtti időszakkal való kontinuitás szálaira bukkanhatunk. Az első évben ugyanis a kutatásokba bevont nyugdijasok között föltünik Móricz Miklós (1886-1966) - Móricz Zsigmond fivére -, aki kanyargós életpályájának jelentős részében, 1931 és 1944 között a Statisztikai Hivatal állományában dolgozott13; Bene Lajos (1903-1977), aki a megelőző fővárosi közigazgatási karrier után 1929-től dolgozott a Fővárosi Statisztikai Hivatalban, amelynek vezetője is volt, majd pedig annak beolvasztása után került át a KSH-ba, ahonnan 1963ban ment nyugdíjba; Theiss Ede (1899-1979), a matematikai modellezés úttörője, akit 1949-ben fosztottak meg akadémiai tagságától, majd 1956-ban nyugdijaztak (Hoóz 2016: 130-133.); Ősy József (1902-?), aki szintén nyugállományú egyetemi tanárként szerepel az MTA elnökségének felterjesztett kutatási tervekben, noha a két világháború között az erdélyi kisebbségi magyar mozgalmak részt vevője volt - az Erdélyi Magyar Földhitelintézet tisztviselője -, s csak 1944-ben kapott a kolozsvári egyetemen magántanári kinevezést. Az említettek közül Móricz csak a legelső évben szerepel, a többiek még a továbbiakban is. Megjelenésük a Népességtudományi Kutató Csoporthoz telepített kutatásokban arra utal, hogy tudatos szándék lehetett az 1945 előtti statisztikához való egyfajta visszakapcsolódás, noha ezt természetesen semmilyen dokumentumban nem irták le 1962/63-ban.

A NKCs-ben folyó kutatások finanszírozásában az MTA-tól érkező juttatások messze kisebb arányt tettek ki (1964-ben a teljes összegnek alig több mint 15\%-át). Az összesen 270 ezer forint „akadémiai célhitel” mellett 1 millió 739 ezer forintot biztositott a KSH, elsősorban az 1960-as népszámlálás feldolgozására szánt költségvetési tételből. Az összesen évi 2 millió forintot meghaladó támogatás a kor viszonyai között nyilvánvalóan bőkezűnek számított, különösen egy néhány fős intézet esetében. Az egyes kutatási projekteket átnézve feltűnő, hogy azok, amelyeket Szabady Egon vezetett - a társadalmi átrétegződés

${ }_{13}$ Tudományos életrajza szerint 1945 után már nem folytatott statisztikusi tevékenységet (Kápolnai 2008). Valóban kérdéses lehet, hogy a 80-hoz közelitő Móricz végzett-e érdemi munkát. Meghívása inkább gesztus lehetett. 
demográfiai hatásainak vizsgálata, valamint a főiskolát és egyetemet végzettek demográfiai jellemzőinek vizsgálata -, sokkal nagyobb keretösszeget kaptak, mint a többi kutatás (elöbbi összesen 270 ezer, utóbbi 50 ezer forintot). A további vizsgálatok között található például a magyar munkásság demográfiáját 1945-ig feldolgozó projekt - Dányi Dezső vezetésével a Párttörténeti Intézetnek és a Történettudományi Intézetnek a munkásság történetére vonatkozó munkaprogramjához kapcsolódva -, a családszerkezeti kutatás, amelyet Tamásy József vezetett, s több más projekt Benkő Dénesné Lukács Ágnes, Klinger András (két projektet is vezetett), Kepecs József, Tekse Kálmán (matematikai módszertani kérdések), Valkovics Emil, Pallós Emil, Acsádi György, Nemeskéri János, Hoóz István vezetésével. Nemeskéri fizikai antropológusként Ivád község - ún. izolátum - kutatásával foglalkozott, ahol a tartós házassági endogámia sajátos antropológiai jegyeket hordozó, illetve régebbi antropológiai adottságokat konzerváló népességet eredményezett. (Ez a kutatás ma talán inkább számítana történeti genetikai kutatásnak, mint demográfiai vizsgálatnak. Nemeskéri a honfoglalók, illetve az Árpád-ház tagjainak fizikai antropológiájával is foglalkozott.) Hoóz István a pécsi egyetem tanszékvezető adjunktusaként a baranyai nemzetiségi népmozgalom címén járási szinten a cigány népesség demográfiai magatartására irányuló kutatást vezetett. ${ }^{14}$

A Népességtudományi Kutató Csoport kezdeti müködésével kapcsolatban fölmerülhet, hogy az első egy-két évben inkább virtuálisan működő kutatóhelyről lehetett szó. A csoporthoz több olyan kutatás került, amelyben a NKCs állományából senki sem vett részt. A kutatóhely nyilván alkalmas volt arra, hogy a KSH munkatársai - részben hivatali, kisebb részt akadémiai finanszírozással - olyan vizsgálatokat, illetve elemzéseket vigyenek végig, amelyek a KSH adatállományaira, apparátusára épültek, ám nem tartoztak a szorosan vett hivatali feladatok közé. Az MTA-val való kapcsolat azért is volt fontos, mert ez legitimálta, hogy itt tisztán tudományos célú alapkutatások folynak, amelyek túlmutatnak a KSH szokásos feladatain.

Összességében a demográfia akadémiai és KSH-beli intézményesülése két ténynek köszönhetően mehetett végbe. Egyrészt a születésszám drasztikus csökkenésének és a politikai hatalom téma iránti érdeklődésének, másrészt annak, hogy voltak olyan szakemberek, akikben megvolt az igény a demográfiai problémák tudományos kutatására és az ambíció a demográfia tudományos intézményesitésére. Az 1960-as évek elejének születésszámai a laikusok számára

\footnotetext{
${ }^{14}$ Az NKCs első éveinek munkatervei és jelentései: MTA Levéltár 167/4. Elnökségi Titkárság Demográfiai elnökségi bizottság; MTA Levéltár 167/6. Dem. Elnökségi Bizottság.
} 
is riasztóan hatottak. Ebben a helyzetben nem lehetett nehéz a kérdéssel foglalkozóknak meggyőzni a különböző felettes szinteket annak szükségességéről, hogy a hosszú távú demográfiai trendek kutatására intézményes formák között is szükség van. Egyértelmünek látszik, hogy az NKCs létrehozatalában részt vevő körben Szabady Egon volt - mind az Akadémián, mind a KSH-ban - a központi, kezdeményező személy. ${ }^{15}$

Az NKCs keretében folyó kutatások ugyanakkor nem csupán a szorosan vett termékenységi vagy demográfiai kérdésekre korlátozódtak, és nem is csak a gazdasági tervezés igényeinek feleltek meg. A társadalmi változások demográfiai vizsgálatának kapcsán tulajdonképpen szociológiai jellegű kutatásokat vittek végig. A társadalmi átrétegződés demográfiai hatásainak vizsgálatához az 1960-as népszámlálásból vettek egy ezrelékes mintát. A mintába kerültek besorolásához kidolgoztak egy rétegződésmodellt. Ez azért is érdekes, mert a KSH más részlegeiben, a Közgazdasági főosztály Társadalomstatisztikai osztályán elsősorban Ferge Zsuzsa vezetésével ekkoriban párhuzamosan folytak, később nagyhatásúvá vált rétegződéskutatások. ${ }^{16}$ Az NKCs kutatásához javasolt rétegződésmodell kevésbé volt árnyalt, mint az, amit Ferge Zsuzsáék alkalmaztak, szorosabban kötődött a két osztály egy rétegsémához. Az NKCs-ben ugyanakkor terveztek egy mikroszintű rétegződésvizsgálatot, három kiválasztott Heves megyei falu átstrukturálódását kívánták részleteiben is vizsgálni. Ehhez pedig egy nagyon árnyalt falusi rétegződésmodellt dolgozott ki valaki - sajnos nem látszik a papírra vetett kutatási tervből, hogy kicsoda - mégpedig több időmetszetre. A TSZ-esítés utáni időkre nézve foglalkozási szempontból homogén és inhomogén háztartásokra nézve alkottak több szempontú tipológiát, amit össze kívántak vetni az 1938-as állapotokkal, amelyhez egy külön, az adott időpontnak megfelelő árnyalt tipológiát kívántak alkalmazni. A két időpont között az 1949es birtokviszonyokat is meg akarták vizsgálni, hiszen azok nyilván nem voltak azonosak a háború előttivel (és persze az 1960-as évek közepivel sem). Ez valószínüleg egy próbavizsgálat lehetett, aminek nyomán 1965-ben végrehajtottak egy hasonló, de immár országos léptékű mintavételes vizsgálatot a falvak átalakulásának tanulmányozására.

\footnotetext{
${ }^{15}$ Szabady Egon 1917-ben született, 1940-től dolgozott a KSH-ban, bár jelentős megszakítással. 1942-ben bevonult katonának, s a hadsereg kötelékében maradt 1948 elejéig, akkor a KSH sürgetésére - századosi rangban - szolgálaton kívüli viszonyba helyezték és visszatért állásába, amely elvileg addig is fönn volt tartva neki. 1946-tól volt az MKP tagja. MNL OL XXXII-23-j- 8. 7 doboz.

${ }^{16}$ Párhuzamosságok persze más tekintetben is léteztek. A Szabady elnökhelyettes által vezetett Népesedési és Szociálstatisztikai főosztályán pl. a '60-as évek második felében létezett Demográfiai Módszertani osztály. Kérdés, hogy mi volt ennek az osztálynak a feladata, miben különült el a tevékenysége az NKCs-től, ahol módszertani kutatások is folytak.
} 
Más, nem szoros értelemben vett demográfiai kutatások is folytak az NKCsben, többek között a kulturális fogyasztásra irányuló, lényegében szociológiai kutatás is. 1964-ben a KSH Művelődésstatisztikai osztályával közösen készítettek felvételt a népesség kulturális helyzetéről. Elsősorban a terjedő televíziózás hatására voltak kíváncsiak, televízió és mozi, televízió és színház relációit vizsgálva, illetve lényegében közvélemény-kutatást folytattak arról, hogy mit néznek, mit miért nem néznek, továbbá mit néznének szívesen a televízióval rendelkezők. Olvasásról, könyvvásárlásról, könyvtárról, zenehallgatásról, múzeumlátogatásról, rádióhallgatásról, koncerteken való részvételről, ismeretterjesztés iránt való érdeklődésről szóltak a kérdések.

Az elsősorban Andorka Rudolf nevéhez kapcsolódó kutatások sem szorosan demográfiai jellegüek voltak. Andorka először a mobilitás kérdéseivel kezdett foglalkozni, ám ezen a témán - Cseh-Szombathy László visszaemlékezései szerint - a KSH „Zászlós urai” nem engedték dolgozni.” Ezért olyan kutatási témát keresett, amely nem volt foglalt, addig nem vonzott senkit. Ez volt az alkoholisták vizsgálata, amit követett a gyilkosoké, majd pedig az öngyilkosoké, amely kutatások végül devianciavizsgálat címszó alatt álltak össze és folytak jó ideig az NKCs-ben, illetve később az NKI-ban. Andorka csak e hosszú kitérő után tért vissza a mobilitás-kutatáshoz.

Természetesen a kutatócsoport, majd intézet profiljának megfelelően - és a születésszámra irányuló érdeklődés által is motiválva - a termékenység is fontos kutatási projekt volt. Ebből a kutatási témából a születésszám alakulásának magyarázatát keresve, a kutatás egy ága a fogamzásgátlás módjainak vizsgálata felé kanyarodott el. Az ekkoriban elterjedő fogamzásgátló tabletták használata állt a kutatás homlokterében, nőgyógyászati egészségügyi intézményekkel együttműködésben próbálták fölmérni - a mintába kerülő nőket névvel, címmel, munkahellyel rögzítve -, hogy milyen fogamzásgátló módszereket használtak a megelőző időszakban. Úgy tủnik, hogy a sok erőforrást felhasználó fogam-

\footnotetext{
${ }^{17}$ „Szigorú hierarchia érvényesült a tekintetben, hogy a Hivatal munkatársai között ki milyen jelentőségú témával foglalkozhasson, hol és mikor hozhassa nyilvánosságra az elért eredményeket. [...] Az első alkalommal a társadalmi mobilitás vizsgálatára végrehajtott adatfelvétel elemzésénél ütközött a hivatali hierarchia rendjébe. Felettesei az anyag kiadásra történő rendezését várták tőle, ő viszont az addig végzett munka hibáira jött rá, és ezeket hozta a téves adatokból már messzemenő következtetéseket levonó feletteseinek tudomására.” Andorka „[a]z első <<rendreutasitás>> után olyan témát keresett, amely egyre növekvő jelentősége ellenére addig még nem keltette fel a hivatali <<zászlós urak»> érdeklődését, mivel gusztustalannak minősült. Ez az alkoholizmus társadalmi hátterének vizsgálata volt. A kutatás nemcsak a téma addigi gazdátlansága miatt volt újdonság, hanem interdiszciplináris jellegénél fogva is úttörő vállalkozásnak bizonyult, valamint áttörés volt abból a szempontból, hogy világossá tette, a társadalmi beilleszkedések zavarai nemcsak a kapitalista múlt csökevényei, hanem a szocialista társadalmi renddel is velejárnak. Az alkoholizmusvizsgálattal társulva a Hivatalban folyó öngyilkosság-kutatásokkal kialakult egy átfogó devianciakutatás, amely mai napig is alapjául szolgál az egyéni magatartásproblémák társadalmi gyökereinek vizsgálatához." (Cseh-Szombathy 2001: 2-3.)
} 
zásgátlás kutatás mellett a koraszülések, a halva születés, a csecsemő- és gyermekhalandóság mint végső soron a felnövekvő újabb generációk létszámát meghatározó tényezők szintén érdekelték a kutatócsoportot. E témában is az egészségügyi intézményekkel együttmüködve folytattak kiterjedt kutatásokat, a szülészeteken minden koraszülöttről, halva születettről és az éretten születettek 20\%-áról, illetve szüleikről véve fel a demográfiai és a szociológiai alapadataikat. Ezt követően megpróbálták nyomon követni a csecsemők fejlődését, védőnőket vonva be a vizsgálatba, a csecsemőtáplálás és -gondozás gyakorlatát igyekeztek felderíteni, rögzítve a csecsemők betegségtörténetét, összekapcsolva a háztartások társadalmi státusára vonatkozó kérdésekkel, amelyek az iskolázottsági, foglalkozási adatokon túl kiterjedtek pl. a háztartás tartós fogyasztási cikkekkel való ellátottságának felmérésére is.

Ez a kutatás bizonyos szempontból közös alapokon állt az ún. biodemográfiai kutatásokkal, amelyek a népesség biológiai állapotának felmérését célozták. Négy bodrogközi faluban folyt például egy módszertani célokat követő vizsgálat, amelynek során a községek lakosságának biológiai-egészségügyi állapotát mérték fel, hogy egy biometriai jelzőszámrendszert dolgozzanak ki a népesség biológiai állapotának statisztikai felméréséhez. Hasonló irányba mentek azok a vizsgálatok is, amelyek a sorkötelesek, illetve a felsőoktatási intézményekbe felvettek biológiai állapotát igyekeztek feltárni. Tulajdonképpen az alkoholistákra és az öngyilkosokra irányuló kutatásoknak is volt egy ilyen szintje, mert a mintába kerültek olyan adottságait is rögzítették, mint a homlokszélesség, az állkapocsszélesség, a fejhossz, a fejszélesség, a végtagok hossza és egy sor más testi adat. Kérdés, hogy ezek a kutatások, amelyek kiinduló előfeltevéseikben (esetleg öröklődő) biológiai jellemzők és társadalmi pozíciók, magatartások valamilyen irányú - összekapcsolódását feltételezték, mennyit örököltek a régebbi szociáldarwinista, illetve eugenetikai gondolkodásból, továbbá, hogy pontosan milyen helyet is foglaltak el az 1960-as években az ilyen biodemográfiai kutatások a hazai és nemzetközi demográfiai kutatási mezőben, a demográfia kérdésfeltevései között. ${ }^{18}$ Egyértelműnek látszik, hogy ez a típusú kérdésfeltevés nem volt idegen a korabeli hatalom, illetve a pártállami apparátusok szemléletétől sem, hiszen különben a felsőoktatásba felvettek, illetve a sorkötelesek ilyen vizsgálatai nem folyhattak volna.

\footnotetext{
${ }^{18}$ Az eugenika történetével foglalkozó tanulmányok sajnos rendszerint a ll. világháború előtti korszakra korlátozzák vizsgálódásaikat (lásd például Turda 2010). Délkelet-európai eugenetikai gondolkodást elemzik a következő kötet tanulmányai, ám szintén a 20. század első felére vonatkozóan és elsősorban nem demográfiai, hanem egészségügyi szempontból: Promitzer et al. 2011. A tanulmánykötetben Magyarország nem kapott helyet.
} 
A születésszámot és a felnövekvő gyermekek számát meghatározó tényezők közül nem csak a biológiaiakra irányult kutatói figyelem az NKCs-ban. A gyermekvállalással és -neveléssel kapcsolatos témákban is "közvélemény-kutatást” folytattak Pongrácz Tiborné vezetésével, amelynek célja az volt, hogy felderítsék a népesedési kérdésekkel kapcsolatos ismereteket, véleményeket és várakozásokat. A kérdőív onnan indult, hogy hány lakosa van a földnek, de végül olyan kérdésekhez jutott el, hogy mi a kérdezett véleménye a család intézményéről, ösztönözné-e gyermekvállalásra a 600 forintos havi gyermekgondozási segély, mi a véleménye a három év alatti gyerekek, illetve a három és hat év közöttiek otthoni, illetve bölcsődei és óvodai neveléséről stb. Rákérdeztek a női foglalkoztatottság alapadatainak ismeretére, továbbá arra, hogy mi a véleményük a mintába kerülteknek a nők feladatairól a családban, a háztartásban, illetve a munkában.

Az NKCs által folytatott kutatások egy része tehát közvetlenül vagy közvetve a születésszám alakulásának kérdéseihez kapcsolódott. Ez nyilvánvalóan politikai szempontból is érdekes és jelentéstelített téma volt. Foglalkoztak ugyanakkor a társadalom átrétegződésének - az urbanizációnak, a nyugdijas korosztály növekedésének, a falusi társadalom átalakitásának - demográfiai hatásaival is, amely témák iránt a politika szintén érdeklődött, ha nem is olyan mértékben, mint a születésszám alakulás a iránt. Végezetül voltak olyan kutatások is, amelyek még közvetve sem igen rendelkeztek politikai relevanciával. Kétségtelenül a demográfus szakmának már az 1960-as években is volt bizonyos autonómiája. A lehetséges és vizsgálatra érdemes kutatási témák körét részben a szakma nemzetközi közössége jelölte ki, amelyekkel elég szoros kapcsolatai voltak a hazai demográfus szakembereknek, másrészt a hazai demográfiai folyamatokból adódtak. A kutatók számára lehetséges volt a kérdésfeltevéseket, kutatási terveket úgy megfogalmazni, hogy azok elnyerjék a felsőbb szintek jóváhagyását, illetve támogatását, ugyanakkor megfeleljenek a demográfia tudomány akkori nemzetközi sztenderdjeinek.

A demográfia intézményesüléséhez és relatív autonómiájának működéséhez természetesen szükség volt arra is, hogy a demográfus kutatóközösség a tudomány területén olyan kompetenciákkal rendelkezzen, amelyek lehetővé tették számukra a nemzetközi beágyazódást is. A termékenység és az azt meghatározó tényezők kutatását TCs-kutatás - termékenység, családtervezés kutatás címszó alatt foglalták össze. Ezek a kutatások kapcsolódtak a Nemzetközi Családtervezési Szövetség (International Planned Parenthood Federation - IPPF) programjához. E szervezet egyik vezetője Szabady Egon volt, s a nyilván Magyarországéval éppen ellentétes népesedési gondokkal küzdő India mellett az egyik 
szárnya a Közel-Keleten, illetve Európában volt.19 Az IPPF be volt csatornázva az ENSZ-hez, illetve az UNESCO-hoz is. Szabady személy szerint is rendkívül jó nemzetközi kapcsolatokkal rendelkezett, illetve maga is pozíciókat töltött be az ENSZ statisztikai szervezetében (egy időben az ENSZ Társadalomstatisztikai Bizottságának alelnöke volt). Az IPPF olyan nemzetközi hálózatot alkotott, amely demográfiai, egészségügyi és családtervezési szakembereknek biztosított nemzetközi kapcsolatrendszert, amelybe való beágyazottság otthoni mozgásterüket is növelte, s vélhetőleg plusz forrásokat tett számukra elérhetővé. Szabady Egon kapcsolatrendszere révén számos magyar demográfus és statisztikus vett részt az ENSZ különböző fejlesztési programjaiban, elsősorban afrikai és közel-keleti országokban járulva hozzá a statisztikai adatszolgáltatási rendszer kiépüléséhez, valamint a demográfiai kutatások beindításához. ${ }^{20}$ A szakmai autonómia megléte mellett persze a közösségen belül voltak olyan személyek, akik nagyobb befolyással rendelkeztek, akik döntéshozatali pozíciókban voltak. A demográfia tudományában minden bizonnyal Szabady Egon volt az, aki össze tudta kapcsolni a politikai szférával, a tudományos intézményrendszer vezetésével a demográfusi kutatói közösséget, továbbá a demográfia nemzetközi kapcsolatait is menedzselte, s így utóbbival szemben védelmező, de egyben hatalmat gyakorló pozíciót töltött be.

\section{A POLITIKA ÉRDEKLŐDÉSE A DEMOGRÁFIAI FOLYAMATOK IRÁNT ÉS FOGADÓKÉSZSÉGE A NÉPESEDÉSPOLITIKAI JAVASLATOKKAL SZEMBEN AZ 1960-AS ÉVEK MÁSODIK FELÉBEN ÉS AZ 1970-ES ÉVEKBEN}

Az NKCs, illetve a demográfia, mint akadémiai keretek között üzött tudomány tehát nem dolgozott közvetlenül politikai elvárások szerint, s nem is vett részt politikai döntések előkészítésében. Az ilyen feladatokat népesedési kérdésekkel összefüggő feladatokat a minisztériumi apparátusok mellett leginkább az Országos Tervhivatal és az MSZMP KB szervei látták el, amelyek alapvetően a KSH adataiból és az NKCs/NKI eredményeiből dolgoztak.

\footnotetext{
${ }^{19}$ Melegh Attila megállapításai szerint a nemzetközi „family planning industry” angolszász finanszírozású volt és az angolszász népesedéspolitikai diskurzusok sémáit követte, amelyek már a 19-20. század fordulójától rasszisták voltak. Az IPPF tevékenységében azonban az 1960-as években úgy tűnik, hogy indiai, közel-keleti, vagy éppen közép-európai szereplök is önálló mozgástérrel rendelkeztek, s a nemzetközi tevékenységben saját céljaikat és szempontjaikat követve vettek részt (Melegh 2000).

${ }^{20}$ Az I.P.P.F.-fel kapcsolatos iratok MNL OL XXXII-23-j. 7.1. 21. doboz.
} 
Az NKCs kutatásainak nem volt közvetlen szerepe olyan döntések előkészitésében, mint például a gyes bevezetése. Utólag vizsgálták az intézkedések hatását. 1967 tavaszán kezdték tervezni Cseh-Szombathy László vezetésével az ugyan azon év január 1-jén bevezetett gyes hatásának vizsgálatát, az első gyesre menő anyákat elérni kívánó kutatással. Az, hogy a gyes előkészítésében az NKCs-nek, illetve a demográfiának mint tudománynak nem volt szerepe, abból is következik, hogy ezt az intézkedést a politikai vezetés nem népesedéspolitikai, hanem munkaerő-gazdálkodási rendelkezésnek tekintette. A gyes vagy valami ahhoz hasonló intézkedés gondolata már az 1960-as évek eleje óta ismert volt, lehetősége többször felmerült a különböző apparátusok munkájában, illetve a politikai vezetés előtt. Az MSZMP KB Államgazdasági Bizottsága 1966 őszén tárgyalta az újraelhelyezkedési segély bevezetését. ${ }^{21}$ A bevezetés előtt álló gazdasági reform miatt azzal számoltak, hogy a megnövekvő felelősséggel rendelkező vállalatok a gazdaságosság érdekében el fogják bocsátani a nem termelő, vagy nem kellően produktív munkaerőt. Az elküldött emberek elhelyezkedése pedig sokáig is eltarthat, mert közben nagy létszámú évjáratok is belépnek a munkaerőpiacra, a vállalatok pedig nem fognak szakképzetlen munkaerőt alkalmazni. Az újraelhelyezkedési támogatás a felmondási idő járandóságainak meghosszabbításaként működött volna, azaz a vállalat fizette volna a bérköltségek között elszámolva. A bevezetendő támogatás így gyakorlatilag munkanélküli segély lett volna. E javaslatnak mintegy alternatívájaként mérlegelték a gyes bevezetését. Bár az Államgazdasági Bizottság először támogatta az újraelhelyezkedési segély bevezetését, ám végül nem ez, hanem a gyes valósult meg. Utóbbi mellett szóló érvnek tekintették, hogy a pedagógusok és a gyermekorvosok véleménye szerint a gyermek két éves koráig jobb a családi nevelés, mint a bölcsődei. ${ }^{22}$ Érv volt az is, hogy nincs elég bölcsőde és újak létesítése, fenntartása költséges lenne, ráadásul a kisgyermekes dolgozó anyák munkája szükségszerüen kevésbé hatékony, és sokat is hiányoznak. És ami a legfontosabb, a dolgozó anyák

\footnotetext{
${ }^{21}$ MNL 288. f. 15/117. ő.e. Előterjesztés az ÁGB 1966. IX. 9. ülésének életszínvonal-politikai javaslatai között. A visszatekintő elemzések - kézenfekvő módon - úgy vélik, hogy a gyes népesedéspolitikai intézkedés volt. PI.: „A kor döntéshozói ezzel elsősorban a drámaian csökkenő születésszám emelését kivánták elérni...” (Szikra 2010: 15-16.). Szintén kifejezetten családpolitikai intézkedésnek fogja fel Tárkányi (1998: 248-249.).

22 Tárkányi (1998) is megállapítja, hogy a pszichológus és az egészségügyi szakértőknek a korban nagyobb szerepe volt, mint a demográfusoknak (vagy szociológusoknak).
} 
átmeneti otthonmaradásával növelhetők a munkalehetőségek. Utolsó mondatként jegyzi meg az előterjesztés: „A segélyrendszer valószínűleg kedvező hatást gyakorolna a népszaporulatra is." ${ }^{33}$

A pártvezetés természetesen foglalkozott közvetlenül népesedési, illetve népesedéspolitikai kérdésekkel is. Az MSZMP KB Államgazdasági Bizottsága 1966-ban tárgyalt egy részletes előterjesztést az ország népesedési helyzetével kapcsolatban. Ez a mai szemmel nézve rendkívül pronatalista szemléletű elemzés ambiciózus célokat kivánt kitűzni. „A végzett számítások alapján a jelenlegi születési arányszám 16-17 ezrelékre való emelése - ami évi 35-40 ezer élveszületéssel többet jelent - látszik szükségesnek ahhoz, hogy több évtized múlva a produktív korúak, az aktív kereső lakosság száma ne fogyjon. A több mint 10 évi születéskiesés lassú pótlásához, népességünk távlati szaporodását is lehetővé tevő növekedéshez azonban 18-19 ezrelékes születési arányszám lenne kívánatos." Az előterjesztés hangsúlyozta, hogy a demográfiai magatartást rendkivül sok tényező alakítja. A nők tanulása, munkába állása mellett a csökkenés irányába hatott a falusi népesség arányának visszaszorulása is, mert ott korábban 50-60\%-kal magasabb volt a termékenység, mint a városban, jelenleg pedig elöregszik a falusi társadalom, mert a fiatalok elmennek a városba. A más rétegbe vagy városba átkerülők pedig új társadalmi csoportjuk magatartását veszik át. Sőt, az újonnan városba kerültek még alacsonyabb termékenységüek is, mint a hagyományos városi foglalkozás-csoportok, amit vélhetőleg a rosszabb lakáshelyzetük magyaráz. A főbérlő házas nőknek is, mint a hagyományos városi foglalkozás-csoportok, amit mindössze 17\%-a, a szülőkkel együttlakóknak 31\%-a, a társbérletben lakóknak 43\%-a, az albérletben lakóknak pedig 51\%-a veteti el gyermekét az első terhességénél. A gyermekes családok sokkal szegényebbek, mint az ugyanolyan foglalkozású gyermektelenek, a családi pótlék pedig még emelt összegével is messze van attól, hogy a gyermeknevelés költségeit fedezze. Az is ok, hogy 1956-57-ben 170 ezer, jobbára produktív korú ember hagyta el az országot. Az előterjesztés leszögezte azt is, hogy a terhességmegszakitás nem oka, hanem eszköze a születésszám korlátozásának, sokan lényegében családtervezési eszközként használják. Ez egészségügyi okokból - a későbbiekben

\footnotetext{
${ }^{23}$ MNL 288. f. 15/117. o.e. A Munkaügyi Minisztérium és a SZOT gyessel kapcsolatos elöterjesztése leszögezte, hogy a „segélyrendszer bevezetése munkaerőgazdálkodási szempontból különösen időszerü, mivel az átmenetileg otthonmaradó anyák pótlásaként jelentkező munkaerő-szükséglet növeli a foglalkoztatási lehetőségeket. 1967. évtől már jelentkezik a demográfiai hullám hatása [azaz nagylétszámú generáció lép munkába] és ez időtől különös jelentőségủ az egyébként el nem helyezhető leányok, valamint a háztartásban lévő nők munkába állási lehetőségeinek megteremtése. A gyermekgondozási segélyrendszer teljes körủ kibontakoztatásának időszaka egybeesik a demográfiai hullám tetőzésének szakaszával." Ez az előterjesztés is csupán a munkaerő-gazdálkodási szempontok mellett említette meg, hogy „,árhatóan kedvező hatást gyakorol a születések számának megfelelő alakulására is." (Monigl 1992: 113).
} 
koraszülésre hajlamosit - nem helyes. A koraszülöttek száma egyre nő, halandóságuk magas. A bölcsődei férőhelyek száma nagyon kevés az igényekhez képest. E helyzetleírás mellett az anyag hangsúlyozta az anyaság és a gyermeknevelés megbecsülésének fontosságát, és elítélően beszélt arról, hogy vannak, akik anyagi és kényelmi okokból nem vállalnak gyermeket, nő a gyermektelen házaspárok száma.

Ezeket a jelenségeket a gazdasági okokon túl politikailag a szocialista rendszer ellen való kihasználhatóságuk miatt is hátrányosnak tartotta az előterjesztés. „A születések számának csökkenése nem a szocialista társadalmak jellemzője, azonban különösen a külföldi reakció hatására itthon is valláserkölcsi és nacionalista álláspontról szívesen itélik a társadalom negatív magatartásának, társadalmi rendszerünk politikájából fakadó következménynek." Azok az intézmények és szervezetek, amelyektöl a döntéshozatal során szokás szerint véleményt kértek a javaslatról, szintén ebből a szempontból kiindulva foglaltak állást a kérdésben.

Az előterjesztés javasolta, a PB mondja ki, hogy „el kell érni” a 16-17 ezrelékes születésszámot, mégpedig úgy, hogy közelíteni kell a tsz-parasztság, valamint a bérből és fizetésből élők családi pótlék rendszerét egymáshoz. Az ötéves tervben előirányzotton felül is emelni kell a két- és háromgyerekes családoknál a családi pótlék összegét (gyerekszám szerint progresszív módon). Fedezetül a gyermektelenségi adó újbóli bevezetését javasolták. Hathatós, korszerủ fogamzásgátló szereket kell forgalomba hozni és nevelő, felvilágositó munkára van szükség az abortuszok számának csökkentése érdekében. Ki kell szélesiteni az abortusz bizottságok hatáskörét, elutasító jogot kell kapniuk egészségvédelmi és szociális szempontból mérlegelve a terhességmegszakitási kérelmeket. A gyermektelenségi adót 4\%-ban javasolták meghatározni a munkába lépéstől a nyugdijba vonulásig, ha valakinek nincs vagy nem volt gyermeke. Beépült a tervezetbe az Egészségügyi Minisztérium javaslata is, amely szerint a gyermektelen vagy egygyermekes kérelmezőnél utasitsák el az abortuszt, ha megfelelö összjövedelemmel, lakással és családi körülményekkel rendelkezik az illető. ${ }^{24}$

Az Államgazdasági Bizottság ülésén az előterjesztés nem minden pontjával értettek egyet, a gyermektelenségi adó bevezetését egyöntetủen elutasították. Az anyag csak a megfelelő átdolgozás után mehetett a PB elé. ${ }^{25}$

A módosítás után az anyag a PB elé került. A legszűkebb pártvezetés tagjainak véleménye a kérdéssel kapcsolatban egyöntetű volt. Mindenki számára magától értetődött, hogy a születésszám csökkenése nagy probléma, és vala-

\footnotetext{
${ }^{24}$ Az Egészségügyi Minisztérium előterjesztésének eredeti változatát lásd Monigl 1992: 91-101.

${ }^{25}$ Az Államgazdasági Bizottság 1966. IX. 9. ülése MNL OL 288. f. 15/117. ő.e.
} 
milyen intézkedéssel ösztönözni kell az emelkedését. Nemes Dezső - a PB tagja, ekkor a Párttörténeti Intézet igazgatója - még egy progresszíven emelkedő gyermektelenségi adó újbóli bevezetését is javasolta. Fock Jenő - a PB tagja, ekkor miniszterelnök helyettes, később miniszterelnök - a családi pótlék összegének emelését tartotta célszerünek, még akkor is ha ennek finanszírozásához emelni kellene néhány - nem közszükségleti - cikk árát. Véleménye szerint, ha azt kommunikálják, hogy erre a magasabb családi pótlék emeléséhez van szükség, akkor azt a társadalom többsége elfogadná. Czinege Lajos - a PB tagja, honvédelmi miniszter - a bölcsődei és óvodai hálózat kiépítését szorgalmazta, mert szerinte a gyermekvállalás akadálya, hogy a dolgozó nők nem tudják kire bízni a kisgyerekeket, mert nincs már nagymama, mint korábban falun, aki vigyázna rájuk. Emellett azt javasolta, hogy aki három vagy öt gyermeket szült, az korábban mehessen nyugdíjba, vagy magasabb nyugdíjat élvezhessen. Komócsin Zoltán - a PB tagja, a KB külügyi titkára - a „szó legigazibb értelmében vett nemzeti érdek"-nek nevezte a születésszám emelését, és a gyerekellenes hangulat megváltoztatásának szükségességéről beszélt. Véleménye szerint egy anya- és gyermekkultuszt kellene felépíteni, csak éppenséggel több ízléssel, mint a Ratkó-korszakban. Ezzel szintén mindenki egyetértett. Kállai Gyula - a PB tagja, ekkor miniszterelnök - a lakáskérdést nevezte döntőnek, és a fiatalok lakáshoz jutásának támogatását szorgalmazta. Biszku Béla - PB tag, a KB adminisztratív titkára - leszögezte, hogy a kérdésben megosztott a társadalom. Az egyik fele tűrhetetlennek tartja a nemzet szempontjából az abortuszt, másik fele viszont helyeseli. Ezen a megosztottságon nem lehet változtatni, az abortusz szigorításának így mindenképpen politikai ára lenne. Ezt az árat azonban vállalni kell, nem lesz később sem olyan alkalom, ami kedvezőbb lenne a szigorításhoz. Azzal, hogy az abortusz bizottságok teljesen formális munkáján változtatni kell, mindenki egyetértett. Fock Jenő azt javasolta, hogy a gyermektelen nőknek, ha főbérleti lakásuk van, ne engedélyezzék az abortuszt. Szerinte ezzel „minden normális ember", a társadalom 90\%-a egyetértene. Egyedül Szirmai István - PB tag, a KB ideológiai titkára - képviselt némileg eltérő álláspontot, véleménye szerint a születésszám csökkenése már megállt, és így a Politikai Bizottságnak nem kellene átvennie azokat az ellenséges megközelítésmódokat, amelyek szerint a gyermekszám csökkenésében valami nagy veszély rejlene. Azon kívül utalt arra is, hogy a Nőtanács nagyon ellenzi az abortusz szigorítását, noha azzal szerinte is foglalkozni kell.

Utolsó felszólalóként Kádár János tette helyre a PB kicsit csapongó megbeszélését. Az első titkár elvtársaihoz hasonló szellemben beszélt, sőt akár még 
túl is tett rajtuk, amikor a fiatalság cinikus hozzáállásáról értekezett. Kijelentette, hogy a jelenlevők kétharmada nem lenne életben, ha a szüleik azt mérlegelték volna, hogy éppen lehet-e gyermeket szülni vagy nem. Leszögezte, hogy „a család nem két fiatal, hanem a gyermek, akit a társadalom vár tőlük”. Kádár szerint az egyik alap probléma az abortusz-rendelet, és az összes ösztönző intézkedés nem ér semmit, ha nem nyúlnak hozzá a rossz rendelethez. A rendelet '56-ban született a forradalom előtti időszakban. Az akkori pártvezetés döntései között a szektás baloldali és a liberális jobboldali intézkedések keveredtek. Az abortuszrendelet az utóbbiak közé tartozik. Korábban a vezetés nagyon rosszul kezelte a kérdést, aztán '56-ban kapkodva, nyomás alatt hoztak egy szintén nagyon rossz abortuszrendeletet, amely „az anyára bízza a döntést, hogy mikor és hány gyermeket kiván világra hozni. Ez liberális álláspont, és mélyen meggyökerezett a köztudatban annyira, hogy a Nőtanácsban jelenleg is ezt vallják. Ez nem azok közé a demokratikus szabadságjogok közé tartozik, hogy írhat-e cikket vagy nem valaki." Kádár nem értett egyet azzal, hogy az abortusz nem oka, hanem eszköze a születésszám csökkenésének. Szerinte oka is, nem csak eszköze. „[A]mit régen a bábaasszonyok és sarlatánok csináltak - egyénileg tették tönkre az anyákat, - most ez nálunk intézményes és törvényes rend - bocsánat a kifejezésért - mert amit most csinálunk, az szisztematikus tönkretétel hatósági engedéllyel és jóváhagyással. [...] A szülőotthonokra ki van írva, hogy szülőotthon, de azok a valóságban hatósági angyalcsináló gyárak. Én ezt nem fogom sehol így mondani, de másképpen erre nem tudok gondolni."

E kirohanások után viszont Kádár konkrét lépésként nagyon is óvatos, megfontolt javaslatot tett. Egyrészt leszögezte, hogy ezt az anyagot a KSH önhatalmúlag, saját kezdeményezésére készítette. ${ }^{26}$ Arra is rámutatott, hogy az éves születésszám a közeljövőben emelkedni fog minden beavatkozás nélkül is, mert ez következik a demográfiai folyamatokból (amit helyesen látott). Azt javasolta, hogy egy széles körủ vita kiprovokálását elkerülendő, az anyagot ne hozzák nyilvánosságra, hanem csak a KB osztályai kapják meg a további munka irányvonalául. A közelgő pártkongresszuson a téma kerüljön elő mint gond, de konkrét megoldási javaslatok nélkül, mert az anyagban lévő ötletek - a családi pótlék emelése, lakáshoz jutás támogatása stb. - még mind nyers, kidolgozandó, tovább vizsgálatokat igénylő kérdések. Kerüljön viszont

\footnotetext{
${ }^{26}$ Ez az anyagban sehol sincs leirva, és az a KB Államgazdasági Bizottságának előzetes tárgyalásain sem merült föl. Mindazonáltal, ha Kádár értesülése helytálló, akkor a KSH - nyilván nem függetlenül a kérdésről ekkoriban nyilvánosan folyó vitától - az egyébként adott feladatain túl is foglalkozott a témával, mi több, képes volt javaslatait a legfelsőbb döntéshozói szint elé is eljuttatni.
} 
be a kongresszusi anyagokba, hogy az abortusz bizottságok müködésének szigorítását meg fogják vizsgálni, hogy az megfeleljen az anya és a társadalom érdekeinek. Ezt Kádár szerint is vállalni kell, még ha „,majd a nagyon felvilágosult nők azt fogják mondani, hogy ez ütközik a szabadságjogokkal. Mit csináljunk? Megvédjük az álláspontunkat!” Végül a PB természetesen elfogadta Kádár javaslatát, amely szerint a pártkongresszusra egy tömör elvi állásfoglalást kell készíteni, ami az abortusz bizottságok gyakorlatának felülvizsgálatáról, majd a családalapitás segítéséről, a többgyermekesek támogatásáról és a kisgyermekes anyák munkahelyi védelméről szól. Egy ilyen kongresszusi döntésre alapozva lehet majd tovább építkezni újabb intézkedésekkel, ha azokat megfelelően előkészítették. ${ }^{27}$

Kádár tehát - ebben az esetben a PB-tagok többségétől eltérően - ismét nem hagyta magát befolyásolni a KSH-ból érkezett népesedéspolitikai javaslatoktól, s csak fokozatosan haladva annyit kívánt lépni a népesedéspolitikai kérdésekben, amennyit szükségesnek vélt a nyomás leszerelésére. ${ }^{28}$ Valószinüleg úgy látta, hogy egy ilyen pártkongresszusi állásfoglalás megnyugtatja a közvélemény születésszám csökkenéséért aggódó részét anélkül, hogy túlságosan provokálná azokat, akiknek fontos az abortusz szabadsága, illetve általában az, hogy az állam ne avatkozzon a magánéletbe, valamint az annak részeként felfogott családtervezés és a gyermekvállalás kérdéseibe. Kádár kongresszusi beszédében ez a következőképp jelent meg:

„Társadalmi kérdéseink közül meg kívánom még említeni a népesedés alakulását. Mint ismeretes, az utóbbi években hazánkban különböző okok következtében erősen csökkent a születési arányszám. Sok túlzó megállapítás is elhangzott erről. Bár mintegy két éve a csökkenés megállt, és nagyon kis mértékủ javulás mutatkozik, mégis úgy tartjuk, hogy államunknak és társadalmunknak is jelentős kérdéséről van szó, amellyel foglalkozni kell. Sokan a születési arányszám növelését leszűkitik a kérdés anyagi (bölcsődei, óvodai férőhelyek, lakáshiány, családi pótlék) oldalára. Kétségtelen, hogy itt többről - társadalmi, szemléleti, egészségügyi és anyagi vonatkozású dolgokról - van szó. A Központi Bizottság azt tartja, hogy nagyon sokrétü, a társadalom, az emberek életének sok vonatkozását komolyan érintő kérdésről lévén szó, csak rendkivül körültekintő vizsgálatok, az érdekeltekkel való beható tanácskozás alapján lehet olyan intézkedéseket kidolgozni, amelyek célszerűek a születési arányszám növekedésének elősegitéséhez. Szükségesnek

\footnotetext{
${ }^{27}$ A Politikai Bizottság 1966. X. 4. ülésének jegyzőkönyve MNL OL 288. f. 5/406. ő. e.

${ }^{28}$ Egy évvel később egyébként Az MSZMP KB Tudományos, közoktatási és kulturális osztálya ismét javasolta az abortusz szigorítását a PB-nek, ami ezt ekkor is elvetette (Monigl 1992: 121-124.).
} 
látszik, hogy az illetékes kormányzati szervek foglalkozzanak a népesedés alakulásával, és a társadalmi szervek bevonásával dolgozzák ki mindazokat az intézkedéseket, amelyek a nők, az anyák, a család, a társadalom érdekének megfelelnek, és a kérdés társadalmi, etikai, közegészségügyi és anyagi oldalát egyaránt átfogják."29

A kongresszus a kérdésről határozatot hozott, ${ }^{30}$ azonban azt követően sokáig nem történtek érdemi lépések - eltekintve a gyes életbe lépésétől, amely a következő év elején, néhány héttel követte a kongresszust, de valójában a róla szóló döntés már természetesen jóval korábban megszületett -, ami a témával foglalkozókból elégedetlenséget váltott ki. Lényeges változást csak az 1973-ban született népesedéspolitikai PB-határozatok hoztak, amelyek a gyes és a családi pótlék - szelektív, a többgyermekeseket támogató - felemeléséről szóltak, kimondták, hogy az állami erőből épült lakások elosztásánál előnyben kell részesíteni a többgyermekes családokat, előirták, hogy a KB Gazdaságpolitikai osztálya vizsgálja meg a gyermektelenek által fizetendő családtámogatási hozzájárulás bevezetésének lehetőségét, továbbá felszólítottak az abortusz-szabályozás szigoritására, amennyiben azt rögzítették, hogy a házasságban, a föbérleti vagy saját lakásban élő 40 évesnél nem idősebb nők nem kérhetnek abortuszt, ha nincs legalább három gyerekük. Emellett a határozat a közvélemény megfelelő irányba való befolyásolását is előirta, és általánosságban a két-, háromgyermekes családmodell elérését tűzte ki célul (Vass 1978: 434-451.). A határozatban tehát testet öltöttek azok a nézetek, amelyeket a PB tagjainak többsége már az előző évtizedben is vallott a népesedési kérdésekkel kapcsolatban. Úgy tűnik, hogy ekkor a pronatalista

\footnotetext{
${ }^{29}$ A Magyar Szocialista Munkáspárt IX. Kongresszusa. 1966. november 28 - december 3. 1966. Kossuth, 31-32. 0.

${ }^{30}$ Az MSZMP IX. kongresszusának határozata: „Hazánk lakossága az 1961-1965. években csak 154000 fővel, mintegy másfél százalékkal nőtt. 1962 óta 1000 lakosra évente 13 élveszületés jut, s ez a szám nemzetközi méretekben is rendkívül alacsony. Ugyanakkor jelentősen kitolódott az életkor felső határa. Öt év alatt a nyugdijaskorúak aránya 17 százalékról 19 százalékra nőtt, a 14 évnél fiatalabbaké pedig 24 százalékról 21 százalékra csökkent. Ha ez az irányzat nem változik, néhány év múlva érezhetően nőni fog az eltartott lakosság száma a munkaképes dolgozókéhoz viszonyitva. Az egész nép érdeke, nemzeti gondunk, hogy ennek okait sokoldalúan vizsgálva és feltárva megfordítsuk a népességszaporulat jelenlegi irányát. Pártunk javaslatára az elmúlt években több izzben megemeltük a családi pótlékot, erőnkhöz mérten bővitettük az óvodai, bölcsődei férőhelyeket, javitottuk a gyermekek felnevelését elősegitő egészségügyi hálózatot. Eddigi erőfeszitéseink nem tudták megoldani a problémákat; továbbra is nagy a különbség a többgyermekes és a gyermektelen családok életszínvonala között. Indokoltnak tartjuk, hogy a családi pótlék 1966-ban végrehajtott emelését, ahogyan azt anyagi erőink megengedik, a későbbi években további lépések kövessék. Azt tervezzük, hogy a termelőszövetkezeti tagok családi pótléka 1970-ig érje el a bérből és fizetésből élőknek szintjét. Gondoskodni kell arról, hogy az anyákat, és különösen a sokgyermekes családokat, nagyobb társadalmi megbecsülés övezze. A kongresszus javasolja megvizsgálni, hogyan lehetne növelni a gyermekes családok anyagi biztonságát és milyen további könnyitéseket nyújthatna a társadalom a dolgozni és tanulni akaró gyermekes anyáknak. Javasoljuk, hogy 1967-ben gyermekgondozási segélyt vezessenek be. Jóval nagyobb mértékben kell lehetővé tenni a gyermekes anyák számára a napi 4-6 órás munkát és a bedolgozást. Következetesen kell érvényesiteni azt az elvet, hogy a lakásépités állami támogatásánál és a lakások elosztásánál a gyermekes családok elönyben részesüljenek. [...] Átgondolt és széles körủ gazdasági, szociális, egészségügyi intézkedésekkel egyidejủleg, a jövőben nagyobb figyelmet kell szentelni a családvédelem, a gyermeknevelés kérdéseinek, és harcolni kell a társadalmi felelötlenség jelenségei ellen." (Vass 1968: 548-549.).
} 
irányba érvényesülő nyomás - amelynek érveit, vagy inkább érzéseit a pártvezetők többségükben osztották - ekkor meg tudott jelenni a PB döntésében. Vagyis a pártvezetés ez esetben félretette a népesedési kérdések, főként az abortusz szabályozással kapcsolatos politikai óvatosságát, amely korábban visszatartotta olyan lépésektől, amelyeket a társadalom nagy része a személyes, hétköznapi szférába való beavatkozásnak látott. A PB határozata után a Minisztertanács részben átültette a gyakorlatba a pártvezetés előírásait. ${ }^{31}$ A határozatból azonban korántsem valósult meg minden, és 1975 után hosszabb ideig nem is születtek újabb kormányzati intézkedések, amelyek a születésszámot kivánták volna befolyásolni.

A PB határozata a születésszám csökkenése miatt aggódó publicisták, irodalmárok egy részénél elismerést váltott ki, és a demográfusok között is voltak, akik (Szabady Egon) mintegy a hivatalos álláspontot képviselve azt hangoztatták, hogy a népesedési problémát az intézkedések megoldották. A demográfus szakma nagyobbik része azonban minden jel szerint nem értett egyet a PB-döntés számos pontjával, mindenekelőtt az abortusz szigorításával. Konszenzusos álláspontnak tűnik körükben, hogy a művi terhességmegszakítás lehetősége nem oka, hanem eszköze a születéskorlátozásnak, ezért az abortusz szigorítása érdemi változást nem tudna előidézni, miközben az illegális abortuszok magasabb egészségügyi kockázattal járnának. Ez persze nem jelentette azt, hogy az abortuszt a demográfusok többsége is ne tartotta volna visszaszorítandónak - már csak azért is, mert hajlamosít a későbbiekben a spontán vetélésre vagy koraszülésre de ezt nem adminisztratív eszközökkel tartották kívánatosnak. ${ }^{32}$

Az abortusz kérdésén túl a demográfusok helytelenítették a népesedéspolitikai hatású intézkedések bevezetésének időpontját is. Ugyanis a gyes bevezetése akkor történt meg, amikor a II. világháború utáni nagyobb létszámú generáció szülőképes korba lépett, az 1973-as népesedéspolitikai határozatok pedig akkor fejtették ki hatásukat, amikor a Ratkó-gyerekek léptek a családalapítás életkorába. Így mindkét esetben egy demográfiai „,hullámhegyet” találtak el az intézkedések, ami azt eredményezte, hogy a bevezetésüket követő években rendkivül sok gyerek született. Ezzel a korösszetétel „,hullámzása” még erősödött is, hiszen hullámhegyek és hullámvölgyek követik egymást a születésszám alakulásában, ami aránylag rövid időközönként feszültségeket generált a gyerekeket befogadó intézményrendszerekben (amikor a kapacitások szűknek, majd pedig részben feleslegeseknek bizonyulnak). Ezek a demográfusi vélemények nemcsak

\footnotetext{
${ }^{31}$ 1040/1973. sz. min. tan határozat. 1973. X. 18.

32 Monigl István később egyenesen arról beszélt, hogy az 1973-as népesedéspolitikai határozatok előkészitése során a demográfia végül is, különösen abortuszkérdésben vereséget szenvedett (Monigl - Dányi 1987).
} 
utólagos értékelések, mivel már az 1960-as évek második felében is megfogalmazódott, hogy a népesedéspolitikai intézkedéseket a születésszám jól előre látható apályaira kellene időzíteni, s így „,kiegyenesíteni” a folyamatot. ${ }^{33}$ 1967-ben a gyes bevezetésénél a gazdasági reformokhoz kapcsolódó munkaerő-gazdálkodási szempontok, 1973-ban pedig a népesedési kérdésekkel kapcsolatos politikai helyzet, illetve vélhetőleg a kapcsolódó politikai érzelmek a pártvezetés számára felülírták a demográfusok által képviselt álláspontot.

\section{DEMOGRÁFIAI KUTATÁS ÉS NÉPESEDÉSPOLITIKA AZ 1980- AS ÉVEKBEN}

A demográfia és politikai vezetés közötti interakció 1980 körül indult újra, amikor már régóta várható módon bekövetkezett a népesség tényleges fogyásának megindulása. Az intézményesített demográfiai kutatás ekkoriban egyfajta válságot élt át. Az NKI létét és müködésmódját a KSH és az Akadémia részéről is újra átgondolták. Egy akadémiai vizsgálat Szalai Sándor szociológus akadémikus vezetésével átvilágította az NKI működését. ${ }^{34}$ Ennek során konzultált a KSH vezetésével is. Vukovich György, aki ekkor ez ügyben a KSH-t képviselte, egy a KSH elnökének irt jelentése szerint azt az álláspontot fejtette ki Szalai Sándoréknak, hogy az NKI-ra, letisztított profillal továbbra is szükség van. ${ }^{35}$ Láthatólag vita tárgyát képezte, hogy milyen jellegű kutatások maradjanak az Intézetnél. Az esetleges megszüntetés mellett olyan opcióról is tárgyaltak, amelyben az NKI egy tervezett, nagyobb társadalomtudományi intézet részévé vált volna. Az NKI további fenntartása melletti érv volt, hogy úttörő szerepet tölt be a szocialista országok demográfiai kutatásaiban, mert más baráti országban ilyen intézmény - főleg olyan nemzetközi kapcsolatrendszerrel és elismertséggel, mint amilyennel az NKI rendelkezik - nincs, és így az egész szocialista tábor érdeke, hogy legalább Magyarország révén legyen a világ demográfiájában képviselve (hasonló érvelések már az 1960-as évek végén is megfogalmazódtak az NKI példaszerepéről).

Végeredményben az a döntés született, hogy az NKI önálló intézet marad, tisztán demográfiai kutatói profillal. Feladata a demográfia elméleti kérdéseinek és

\footnotetext{
${ }^{33}$ A KSH-tól elindult 1966-os népesedéspolitikai javaslat: MNL OL 288. f. 15/117. ő.e.

${ }^{34}$ A ma már kevéssé ismert Szalai Sándor szociológus az MTA Kutatásszervezési Intézete Tudományszervezési Csoportjának tagjaként igen befolyásos alakítója volt az MTA-hoz kapcsolódó tudományos intézményrendszernek az 1960-as évek közepétől az 1980-as évek elejéig. Szalai 1912-ben született, német és svájci egyetemeken tanult, 1945-ben ő volt a politikai ügyész Bárdossy László népbírósági perében. Ekkor szociáldemokrata pártkáder volt, majd egyetemi tanár lett. Közismert volt, hogy 1950-től 1956-ig börtönben ült.

${ }^{35}$ Vukovich jelentése 1980. III. 10. KSH Irattár B-1.1. 61. doboz.
} 
módszereinek kutatása, olyan munkamegosztásban, hogy a KSH Népesedésstatisztikai főosztálya megfigyeli és leírja a népesedési folyamatokat, az NKI pedig a folyamatok okait, magyarázatait kutatja, tehát alapkutatásokat végez (hasonló kompetencia elkülönítéseket már az 1960-as évek végén is papírra vetettek). ${ }^{36}$ Elkerült tehát az NKI-tól a mobilitás, a területi egyenlőtlenségek, az életmód, az időmérleg, illetve a beilleszkedési zavarok kutatása, maradtak a „tiszta demográfia”, a biodemográfiai és történeti demográfiai kutatások (beleértve a paleodemográfiát és a Nemeskérinek köszönhetően még mindig zajló ivádi izolátum-kutatást).

Az átalakulást új vezetőként Monigl István vezényelte le, aki korábban az MSZMP KB apparátusában és az Országos Tervhivatalban dolgozott. Az átalakítás együtt járt elbocsátásokkal, elküldtek hét kutatót, és sokakat az adminisztratív, illetve az adatfeldolgozó munkatársak közül. (Korábban kevesebb kutatói státus volt az NKI-ban, mint nem kutatói.) Így 16 kutató maradt. Ugyanakkor 1983-ig 11 új kutató lépett be, igaz közülük néhányan mint „magas tudományos színvonalon dolgozó” nyugdíjasok részfoglalkoztatásban - például a könyvtárból nyugdíjba menő Dányi Dezső -, s így már többséget alkottak a kutatók az adminisztratív dolgozókkal szemben. Egyúttal megszüntek az addig létezett osztályok az Intézeten belül, helyettük csak meghatározott időre életre hívott témacsoportok jöttek létre, amelyek egy-egy kutatási projekten dolgoztak és csak annak időtartamáig léteztek, a témacsoportok vezetőit az Intézet igazgatója nevezte ki. Monigl az Intézet átalakitásáról készített beszámolóban hangsúlyozta, hogy a kutatók minőségi fejlesztése is fontos cél, az Intézet állományából többen tudományos fokozatot szereztek, illetve elkezdték a fokozatszerzési eljárást. A KSH pártbizottságának készített beszámolóban azt is hangsúlyozta Monigl, hogy az Intézetben nagyon alacsony a párttagok aránya - rajta kívül Hablicsek László, aki a pártcsoport felelőse volt és Dányi -, ezért cél a párttagok arányának emelése, amit az új felvételeknél figyelembe kell venni. Ezt a célt később részben sikerült is elérni, $\mathrm{S}$. Molnár Edit, Káposztás Ferenc, Munkácsy Ferenc és mások - esetleg csak részleges - foglalkoztatásával 1983 végére a kutatók 41\%-a volt párttag.37

Az NKI újjászervezése egybeesett azzal a - demográfusok által régen előre jelzett - időszakkal, amikor Magyarország népessége abszolút számban is fogyni kezdett. 1978-ban Szabady Egon, Monigl István, Klinger András és Tamásy

\footnotetext{
${ }^{36}$ Föltehető, hogy a Népesedésstatisztikai főosztályon -, amelynek adatokat kellett szolgáltatnia az NKI elemzéseihez - gyakran érezték úgy, hogy az utóbbi intézmény helyettük aratja le a tudományos babérokat azokkal az adatokkal, amelyeket tőlük kap, s amelyeket ők is föl tudnának a hivatalosan elvárt módokon túl, alapkutatások szempontrendszere szerint is dolgozni.

${ }^{37}$ A felülvizsgálat egyes dokumentumai és Monigl beszámolói az 1981-es évben végzett munkáról, Hablicsek pártcsoportbizalmi beszámolói: KSH Irattár B-1.1. 61. doboz.
} 
József - az Országos Tervhivatal demográfiai munkacsoportjaként elkészített egy népesedési anyagot, ami akkor a PB elé is került. A népességfogyás tényleges megindulásával a népesedési helyzet ismét átlépte a politikai döntéshozók ingerküszöbét, amire egyes demográfusok úgy tünik, tudatosan számítottak is. 1980ban Monigl István, Józan Péter, Klinger András és Kamarás Ferenc elkészitettek egy népesedéspolitikai koncepciótervezetet, amely meg is jelent (Klinger et al. 1988 [1980]..$^{38}$ A KSH elnöke egy felterjesztésben felhívta a pártvezetés figyelmét a népesség alakulásában bekövetkező fordulatra, amely válaszul a folyamatok elemzésére és javaslattételre adott utasitást. Egy Kornidesz Mihály, az MSZMP KB Tudományos, Közoktatási és Kulturális osztályának vezetője által aláírt „témavázlat" a népesedési helyzettel és a népesedéspolitikával foglalkozó PB-előterjesztéshez pontosan ugyanazzal a tartalomjegyzékkel rendelt meg egy elemzést, amilyet az említett demográfusok kidolgoztak. ${ }^{39}$ Monigl István, Őry Imre, Klinger András által készitett anyagot azután a Politika Bizottság 1981. február 17-én megtárgyalta, és annak alapján egy népesedéspolitikai koncepciótervezet kidolgozására adott utasítást. ${ }^{40}$ Kádár János a PB vitájában kifejtette, hogy elemezni kellene az első és a második gyerek megszületésének anyagi ösztönzését, hiszen abból lehet három. Nem csak anyagi okai vannak szerinte az alacsony gyermekszámnak: rossz a közfelfogás, romlott a közerkölcs, a tartós fogyasztási cikkek elöbbre valók, mint a gyermek a családi rangsorolásban. Magas a válások aránya. Jó, hogy csökkent az abortusz, de káros a széles körben elterjedt tablettás védekezés. A gyes jó, bár megjegyezte, hogy eredetileg munkaerőpolitikai és nem népesedéspolitikai intézkedés volt. Gondolkozni kell azon, hogy miként lehetne dolgozni a gyes alatt úgy, hogy az ne csökkentse a szülési kedvet. Változtatni kell a közszellemen a válás megítélése tekintetében. Leszögezte, hogy az anyag pillanatképet tartalmaz, kellene egy átfogó népesedési program részvizsgálatok alapján, új javaslatokkal az 1973-ban elfogadott népesedéspolitikai határozatokhoz képest. A PB ennek megfelelően el is határozta, hogy egy bizottság dolgozzon ki előterjesztést, és a bizottság tagjait is megnevezte. Ehhez felállt egy széles körü szerkesztőbizottság, többségében a KB apparátusának különböző osztályaihoz tartozó munkatársakból, de Monigl és Klinger is tagjai voltak, a tényleges munkát a PB döntésének megfele-

\footnotetext{
${ }^{38}$ A szöveg burkoltan birálta az 1973-as népesedéspolitikai határozatot, amiért az voluntarista módon fogalmazta meg a célokat, és túlzott reményeket táplált a népesedési folyamatok befolyásolhatóságát illetően.

39 KSH Irattár B- 1.1. 72. doboz.

${ }^{40}$ A PB elé került előterjesztés megállapitotta, hogy szük a szülöképes korosztály, hogy a családok nem valósitják meg az eltervezett gyerekeket, sok az egygyermekes család, s bár az abortusz valamelyest visszaszorult, ám a fogamzásgátló tabletták használata viszont rendkívül elterjedt. A születésszám mellett azonban részletesen foglalkozott a halandóság kérdéseivel is.
} 
Iően Monigl, Klinger és Zafír Gyula végezte. Úgy látszik, hogy e demográfusok a pártvezetés számára személyükben, de legalábbis nevük révén ismert szakemberek voltak. ${ }^{41}$ Az előkészítésbe számos intézményt bevontak, majd az elkészülő anyagot 1981 júniusában egy szokatlanul széles körü konferencián vitatták meg, amelyet az MTA és a KSH rendezett. A Kádár-korszaknak állandó sajátossága volt az időnként abszurd módon széleskörű egyeztetés - ahogyan a korszak névadója is széles körben egyeztetett, és testületi döntésekként elfogadott formában szerette érvényesíteni az akaratát - ám ebben az esetben az egyeztetésbe bevont szervezetek listája nem csak a különböző minisztériumokat, Tervhivatalt, MTA-t, Nőtanácsot, Szakszervezetek Országos Tanácsát, Vöröskeresztet, Környezetvédelmi Hivatalt, MSZMP KB osztályokat, KISZ KB-t, stb. foglalta magába. ${ }^{42}$ Erre a konferenciára meghívtak számos írót is, akik korábban ismertté váltak népesedési kérdésekről szóló publicisztikáikkal. A konferenciára készülve az NKI megbízásából elkészítették a meghívott irodalmárok - Bertha Bulcsú, Bor Ambrus, Csák Gyula, Csoóri Sándor, Fekete Gyula, Lázár István, Mezei András, Varga Domokos és Zám Tibor - munkásságának kommentált bibliográfiáját. A könyveik összegyűjtése mellett átnézték az Élet és Irodalom, a Nők Lapja, a Valóság és a Vigília (!) évfolyamait 1970-től kezdve, alkalmilag még a Kortárs, a Jelenkor és a Világosság is bekerült a merítésbe. A bibliográfiák mellett röviden jellemezték az egyes írókat. Összegzésként megállapították, hogy inkább az 1970-es évek első felében volt aktivitás népesedési kérdésekben az írók részéről. Itt kivétel a Nők Lapja, ahol rendszeresen voltak a gyermeknevelés, a házasság, vagy a válás kapcsán olvasói levelekben viták, amelyeket mindig Fekete Gyula értelmezett és kommentált. Ő a Nők Lapjában megjelent anyagok alapján egy levélszociográfiának nevezett könyvet is megjelentetett. Az irodalmárokra irányuló gondos előkészítés azután annyiban kárba veszett, hogy az írók végül mégsem vettek részt a konferencián. Ám a továbbiakban, amikor a konferencia után az anyagot még egyszer átdolgozták, s újabb tanácskozásokat folytattak, akkor a „tudományos és az irodalmi élet kiválóságaival” is konzultáltak - nyilván abból a körből valakikkel, akik a konferenciára is meghívottak lettek volna - majd a Politikai Bizottság 1981. szeptember 29-én megtárgyalta, s végül a döntés nyomán a Minisztertanács 1981. november 26-án határozott arról, hogy az elkészült anyag alapján ki kell dolgozni egy hosszú távú népesedéspolitikai tervet, amely az előre jelezhető folyamatok alapján tartalmazzon konkrét intézkedéseket. Ezt a feladatot az Országos Tervhivatalban felállított népesedéspolitikai ad hoc bizottságnak

\footnotetext{
${ }^{41}$ Az 1981. II. 17. PB-ülés jegyzőkönyvének kivonata. KSH irattár B- 1.1. 72. doboz

42 KSH irattár B- 1.1. 72. doboz.
} 
kellett volna megoldania, ám itt a munka évekig elakadt. 1984 februárjában ismét arról döntött a PB, hogy népesedéspolitikai intézkedésekre szükség van, a Minisztertanács pedig arról, hogy az intézkedések tervének kidolgozását egy miniszterhelyettesekből álló tárcaközi bizottságra bízzák. Vagyis megemelték ezzel a döntéselőkészités szintjét, mert az OT ad hoc bizottságában többnyire a különböző tárcák illetékes főosztályvezetői vettek részt, kiegészülve néhány demográfus szakértővel. Az előkészített anyagról ismét konzultáltak az irodalmi élet „jeleseivel” is. A tervezettel kapcsolatos komoly tartalmi vitákban végül is a PB 1984. augusztus 28-án döntött (Vass 1988: 730-735.). Ekkor már - a demográfusok szemléletének megfelelően - nem csak a születésszám javítását célzó intézkedésekről született határozat. Bár nagy fontosságot tulajdonítottak a gyed bevezetésének, a családi pótlék tervezett többlépcsős emelésének, a bölcsődei és óvodai hálózat fejlesztésének, továbbá ismét csak a gyermekvállalással kapcsolatos szemléleti változásoknak, sőt a válás arányának lehetséges visszaszorítását is célnak tekintették -, mert a stabil családokban több gyerek születése volt várható -, ám mindemellett a halandóság alakulásának is figyelmet szenteltek, különösen a középkorú korosztályok esetében. Ezzel összefüggésben az alkoholizmus, a dohányzás és az egészségtelen életmód kérdéseire is kitértek, és intézkedéseket vártak ezekben a témákban is. Fontosnak tartották a koraszülések visszaszorításának szükségességét mint a „népesség biológiai állapota” javitásának egyik elemét. A határozat utalt arra is, hogy helyes volt a tervezetet egyeztetetése az irodalmi élet kiemelkedő szereplőivel. A PB-határozat nyomán a Minisztertanács 1984. szeptember 27-én elfogadta a maga határozatait, amelyek értelmében 1985. január 1-től életbe lépett a gyed, és további intézkedéseket is elindítottak a kitűzött célok elérése érdekében. ${ }^{43}$

Az előkészités időszakában Monigl István, Nyitrai Ferencné, a KSH elnöke és Lázár György, a Minisztertanács elnöke között némi huza-vona volt megfigyelhető. Lázár nem értette, hogy miért kell a '80-as évek elején újabb népesség-előreszámításokat készíteni, amikor 1978-ban már készültek ilyenek. Nyitrainé válaszában - Monigltól származó érvelésre támaszkodva - kifejtette, hogy 1978 óta a népesedési helyzet váratlanul kedvezőtlenül alakult, így az 1981-es népszámlálás adataira támaszkodva lehetséges és szükséges is egy új, pontosabb előreszámítás elkészítése. Lázár a kézhez kapott előreszámításokon rendkívül megütközött, s egy saját kéziratos visszajelzésben érdeklődött a KSH elnökénél, hogy az adatok

\footnotetext{
${ }^{43} \mathrm{~A}$ gyed elvileg eltért a családpolitika addigi intézkedéseitől, mint a gyes és a családi pótlék, amelyekre mindenki jogosult lehetett, és összegük is azonos volt mindenki számára - bár az 1960-as években ez a családi pótlékra nem igaz, csak 1974re válik univerzális juttatássá - a gyed viszont munkaviszonyhoz kötött és értékben a korábbi keresettől függỏ támogatás.
} 
szakértők által megvitatottak és ellenőrzöttek-e. Nyitrainé válaszában leszögezte, hogy az adatok többszörösen visszaellenőrzöttek, illetve az MTA-val és más demográfus szakértőkkel is megvitatottak. Ezek után Lázár György már csak az adatok nyilvánosságra hozatalával kapcsolatban aggodalmaskodott. Monigl a nyilvánosság mellett érvelt. Álláspontja szerint a prognózisok visszatartásának nem lenne értelme, mert az éves adatokból úgy is kikövetkeztethető, hogy nagymértékű csökkenés várható. Ráadásul az ENSZ szervei is elvárják a népesedési prognózis elkészítését, s ha ilyet Magyarország hivatalosan nem publikál, akkor az ENSZ szakszervei készítenek becslést, ami semmivel sem lesz kedvezőbb az NKI-ban készültnél. Nyitrainé végül mégis csak a „szolgálati használatra” jelzéssel engedte publikálni az anyagot, azaz az államigazgatás szervei (beleértve a tanácsokat) megkaphatták, ám publikálására nem került sor. ${ }^{44}$ Monigl csak az 1984-es népesedéspolitikai határozatok után tudta elérni, hogy a „szolgálati használatra” minősítést feloldják, mivel a nyilvános népesedéspolitikai határozat a főbb adatokat tartalmazta. Az 1980-as években egyébként tudatos törekvés volt - éppen olyan kritikákra válaszul, amelyek arról szóltak, hogy a népesedési kérdésekben a nyilvánosságban nem szakemberek, hanem amatőrök kezében van a kezdeményezés - arra, hogy az NKI nagyobb nyilvánosságot teremtsen magának. Lényegesen bővítették azon újságírók és szerkesztőségek körét, akik megkapták a kiadványokat, s elvileg minden egyes kutatás lezárultával döntöttek arról, hogy az eredményekről melyik napilapban adjanak közre tudósításokat. Monigl maga is próbált jelen lenni a szélesebb nyilvánosságban. A Társadalmi Szemlében - azaz a párt elméleti folyóiratában - publikált ebből a célból, illetve az 1980-as években néhányszor interjú is jelent meg vele a Népszabadságban. Ezek többhónapos előkészítés után láttak napvilágot, amelynek során - amint az az újságíróval való levelezésből látszik - Monigl a neki feltett kérdésekbe is belenyúlt. Mindenesetre szükségesnek érezte, hogy olyan események kapcsán, mint az 1981-es konferencia, vagy az 1984-es népesedéspolitikai határozatok a Népszabadságban is megnyilvánuljon, és az általa kívánatosnak tartott irányba orientálja a közvéleményt. ${ }^{45}$

A hazai demográfiai kutatásokban, az NKI tevékenységében az 1980-as évek második felében újabb „hullámvölgy” figyelhető meg. A források láthatólag megcsappantak, egyre kevesebb kutatási program futott, különösen 1986-tól kezdve, majd az évtized utolsó éveiben a fizetések is elmaradtak a KSH más részlegeihez képest. Gond volt a könyvtár további gyarapítása, a dologi költségek fedezése is. A lecsökkent finanszírozás mellett 1987-ben már azt is leszögezték,

\footnotetext{
${ }^{44}$ Lázár - Nyitrainé és Monigl levélváltásai, más iratok mellett: KSH Irattár B-1.1. 61. doboz.

${ }^{45} \mathrm{KSH}$ Irattár B - 1.1. 62. doboz.
} 
hogy az NKI-nak önálló kutatóvállalattá való átszervezése - amely tehát ötlet szinten felmerült - nem lehet megoldás, nem segítene a pénzügyi gondokon. ${ }^{46}$ Ekkor már a Kutatóintézetnek egyre inkább egy megváltozó szerkezetű nyilvánosságban kellett müködnie. A rendszerváltás közeledtével egyre többféle szervezet - például az MDF, amelynek nevében Kováts Zoltán nyilatkozott többször népesedési kérdésekről - hallatta véleményét demográfiai témákban. Ezeket az NKI - többnyire Monigl vagy Hablicsek által - igyekezett megválaszolni. Ezzel az Intézetnek és a demográfus szakmának fokozatosan a nyilvánosság és a politikai erőviszonyok egy új konstellációjához kellett alkalmazkodnia, 1989-1990-től pedig az állampárti helyzetben lévő MSZMP eltúnésével - más társadalomtudományokhoz hasonlóan - új helyzetbe került a demográfiai kutatás is.

\section{ÖSSZEGZÉS}

A demográfiai kutatások 1950-es évek végi újraindulása, majd kicsivel későbbi intézményesülése nyomán legalább akkora autonómiát élvezett a kádárizmusban, mint más társadalomtudományok, még akkor is, ha a legfontosabb kutatómühelye, az NKI egy államigazgatási intézmény, a KSH részeként működött. Az MTA-val való kapcsolatok és az alap-, illetve módszertani kutatások szükségességének elismerése biztosította a demográfia relatív autonómiáját, amit erősitett a nemzetközi beágyazottság is. Népesedéspolitikai kérdésekben a kormány és a pártvezetés sem tekintette az NKI-t közvetlenül a maga döntés-előkészitő apparátusa részének. Ilyenként a KB osztályai és az Országos Tervhivatal szolgáltak. Ezek a szervezetek kaptak utasításokat ilyen témájú anyagok összeállítására, s az NKI kutatási eredményei közvetítésükkel jutottak el a döntéshozók szintjére. Kitapintható az is, hogy a demográfusok körében elkülönült az a csoport, amelyik otthonosabban mozgott a központi pártapparátus, illetve az OT világában attól, amelyik inkább szorosan akadémiai értelemben foglalkozott demográfiai kutatásokkal. A két csoport szakmai kompetencia és felkészültség tekintetében - ezt fontos hangsúlyozni - nem különbözött. A hazai demográfia kitűnő nemzetközi kapcsolatokkal rendelkezett, beágyazott volt a tudomány nemzetközi intézményeibe és vérkeringésébe, talán még nagyobb mértékben is, mint más társadalomtudományok.

A demográfusok egy része kétségtelenül céljának tekintette, hogy befolyásolja a politikai döntéshozatalt. Ennek nyomai a Kádár-korszak minden évtize-

\footnotetext{
${ }^{46}$ KSH elnökség állásfoglalása 1987. X. 14. KSH irattár B - 1.1. 63. doboz.
} 
déből fellelhetők, noha nem volt folyamatos ez a törekvés. A népesedéspolitikai lépések 1975-tel kezdődő megtorpanásáért például Monigl szerint részben a demográfusok is felelősek, mert ebben az időszakban 1980-ig nem tettek kezdeményező lépéseket, nem dolgoztak ki és juttattak el javaslatokat a politikai vezetés elé, noha ezt korábban és később is megtették. ${ }^{47} \mathrm{Az}$ a tény, hogy a demográfusoknak, vagy talán inkább bizonyos csoportjuknak, akik a párt és az állami apparátusokkal kapcsolatban álltak, volt erre lehetősége természetesen nem jelenti azt, hogy elképzeléseik minden további nélkül átkerültek a politikai döntések szintjére. A pártvezetés időnként ellenállt ezeknek, máskor pedig lépett ugyan, de nem a demográfusok szakszerűnek tekintett elvárásai szerint döntött, mint például az 1973-as népesedéspolitikai határozatok esetében. Ugyanakkor más szakértői csoportok is tevékenykedtek népesedési kérdésekkel kapcsolatban. A demográfusokban tudatosult is, hogy a Ratkó-intézkedésektől kezdve az 1970-es évekig családpolitikai témákban (a támogatási formáktól az abortusz kérdéséig) pszichológus, pedagógus és orvos szakértőkkel is rivalizálniuk kellett, akik szintén befolyásolni igyekeztek a döntéshozókat (Tárkányi 1998, Monigl 1987).

A hatalom képviselőit természetesen sajátos politikai szempontjaik vezették, és csak ezek függvényében engedtek teret a szakma felől érkező javaslatoknak. A pártvezetést népesedéspolitikai döntéseiben befolyásolta a közvélemény, ami a korszak nyilvánosságának sajátos szerkezetében irodalmárok, publicisták tevékenységét jelentette leginkább. Ezt részben politikai nyomásként érzékelték, részben egyet is értettek a népesedési kérdéseket firtató írócsoport némely előfeltevésével, megközelítésmódjával, amint azt a PB vitáinak szövegei mutatják. A témában megnyilatkozó írókat lényegében politikai szereplőkként kezelték, amikor meghívták őket a népesedési konferenciára, illetve, amikor konzultáltak velük a készülőben lévő népesedési koncepcióról. Bizonyára nem konkrét javaslatokat vártak tőlük, hanem inkább azért igyekeztek bevonni őket az intézkedések előkészitésének folyamatába, hogy esetleges nyilvános kritikájukat leszereljék. Összességében azonban a népesedéspolitika nem alakult sem a közvéleményben ezt tematizáló publicisták, sem a demográfusok elképzeléseinek megfelelően, akik már a népesedéspolitikai intézkedések időpontját is szerencsétlennek tartották. A tényleges magyar népesedéspolitikai lépések részben az ő tevékenységük eredőjeként, ám ugyanakkor - nem meglepő módon - jelentős mértékben gazdasági, illetve gazdaságpolitikai igényekhez igazodva, és végül mindig a politikai szféra (amelyben a döntéshozóknak mozogniuk kellett) saját logikájának megfelelően születtek meg.

\footnotetext{
${ }^{47}$ Monigl álítása az előadását követő vitában (Monigl 1987: 44-45.).
} 


\section{FORRÁSOK}

KSH Irattár B - 1.1. 61. doboz.

KSH Irattár B - 1.1. 62. doboz.

KSH Irattár B - 1.1. 63. doboz.

KSH Irattár B - 1.1. 72. doboz.

MNL OL 288. f. 5/267. o. e.

MNL OL 288. f. 5/406. ő. e.

MNL OL 288. f. 15/47. ö. e.

MNL OL 288. f. 15/117. ő. e.

MNL OL XXXII-23-j. 7.1. 21. doboz.

MNL OL XXXII-23-j. 8. 7. doboz.

MTA Levéltár 167/4. Eln. Titkárság. Demográfiai Elnökségi Bizottság.

MTA Levéltár 167/6. Eln. Titkárság. Demográfiai Elnökségi Bizottság.

\section{IRODALOM}

Cseh-Szombathy László 2001: Andorka Rudolf (1931-1997). In Emlékbeszédek az MTA elhunyt tagjai felett 1999/2000. MTA, Budapest, 1-8.

Faragó Tamás 2015: Három évtized. A KSH Könyvtár Történeti Statisztikai Kutatócsoportjának története (1954-1985). KSH Könyvtár, Budapest.

Greenhalgh, Susan 1996: The Social Construction of Population Sciences. An Intellectual, Institutional and Political History of 20th Century Demography. Comparative Studies in Society and History, 38(1), 26-66.

Heller Mária - Némedi Dénes - Rényi Ágnes 1990: Népesedési viták Magyarországon 1960-1986. In Monigl István (szerk.): Népesedési viták Magyarországon 1960-1986. Tudományos vitaülés. KSH NKI Kutatási jelentések, 37, KSH NKI, Budapest, 13-125.

Hoóz István 2016: A demográfia oktatása a jogász és a közgazdászképzésben. Pécsi Tudományegyetem Állam- és Jogtudományi Kara, Pécs.

Kápolnai Iván 2008: A statisztikus Móricz Miklós. Statisztikai Szemle, 86(2), 165-184.

Káposztás Ferenc - Monigl István (szerk.) 1987: Népesedéspolitika; tudományos kutatás és társadalmi cselekvés. KSH NKI Kutatási Jelentések, 31, KSH NKI, Budapest.

Klinger András - Monigl István - Józan Péter - Kamarás Ferenc 1988 [1980]: Népesedési helyzet az 1970-es és az 1980-as években, népesedéspolitikai teendők. In Monigl István (szerk.): A távlati tervezés keretében született népesedéspolitikai koncepciók, 1968-1982. KSH Népességtudományi Kutató Intézet Kutatási Jelentései. Demográfiai Tájékoztató Füzetek 3. KSH NKI, Budapest, 221-268.

KSH NKI 1959: A magyar demográfia tíz éve. Demográfia, 2(1), 5-11. 
Melegh Attila 2000: Az angolszász globális népesedéspolitikai diskurzusok alakulása a 20. században. Lépések a pro- és antinatalista népesedéspolitikák összehasonlítása irányában. Replika, 39, 157-175.

Monigl István (szerk.) 1988: A távlati tervezés keretében született népesedéspolitikai koncepciók, 1968-1982. KSH Népességtudományi Kutató Intézet Kutatási Jelentései. Demográfiai Tájékoztató Füzetek 3. KSH NKI, Budapest.

Monigl István (szerk.) 1990: Népesedési viták Magyarországon 1960-1986. Tudományos vitaülés. KSH NKI Kutatási jelentések, 37, KSH NKI, Budapest.

Monigl István (szerk.) 1992: Népesedéspolitika és fontosabb dokumentumai az 1960-as évtizedben Magyarországon. Dokumentumgyüjtemény. KSH Népességtudományi Kutató Intézet Kutatási Jelentései. Demográfiai Tájékoztató Füzetek 12, KSH NKI, Budapest.

Monigl Isván - Dányi Dezső 1987: Népesedéspolitikánk történeti előzményei és alapkérdései. In Káposztás Ferenc - Monigl István (szerk.): Népesedéspolitika; tudományos kutatás és társadalmi cselekvés. KSH NKI Kutatási Jelentések 31. KSH NKI, Budapest, 13-30.

MTA Demográfiai Elnökségi Bizottság 1963: Az MTA Demográfiai Elnökségi Bizottságának ülései. Demográfia, 6(1), 109-113.

Promitzer, Christian - Trubeta, Sevasti - Turda, Marius (ed.) 2011: Health, Hygiene and Eugenics in Southeastern Europe to 1945. CEU Press, Budapest - New York.

Szikra Dorottya 2010: Családtámogatások Európában történeti perspektívában. In Simonyi Ágnes (szerk.): Családpolitikák változóban. Szociálpolitikai és Munkaügyi Intézet, Budapest, 9-19.

Tárkányi Ákos 1998: Európai családpolitikák: a magyar családpolitika története. Demográfia, 41(2-3), 233-268.

Thirring Lajos 1959: A nemzetközi Népességtudományi Unió és magyar kapcsolatai. Demográfia, 2(2-3), 408-411.

Turda, Marius 2010: Modernism and Eugenics. Palgrave, London.

Vass Henrik (szerk.) 1968: A Magyar Szocialista Munkáspárt határozatai és dokumentumai 1963- 1966. Kossuth, Budapest.

Vass Henrik (szerk.) 1978: A Magyar Szocialista Munkáspárt határozatai és dokumentumai. 1971-1975. Kossuth, Budapest.

Vass Henrik (szerk.) 1988: A Magyar Szocialista Munkáspárt határozatai és dokumentumai. 1980-1985. Kossuth, Budapest. 


\section{HISTORY OF THE HUNGARIAN DEMOGRAPHIC RESEARCH INSTITUTE AND POPULATION POLICY FROM THE 1950'S UNTIL 1989 IN HUNGARY.}

\section{ABSTRACT}

The article investigates the history of the Hungarian demographic research with special respect to the interaction between the scientific community and political power, and to the measures of population policy. The demography was institutionalized at the end of the 1950's and at the beginning of the '60's, but actually was based on the scientific tradition of the pre-socialist era. The foundation and history of the Hungarian Demographic Research Institute shows, that the discipline got a relative scientific autonomy and an international embeddedness during the decades of Kádár-regimes. The research centers of the Hungarian demography did not contribute directly to the elaboration of the population policy measures of state-socialism, and therefore demographers could not directly influence these political decisions, although some of them tried to intervene in decision-making. The article explores the intentions of political decision makers that shaped population policy in the socialist period. 